\title{
Infectious Diseases, Trade, and Economic Growth: a Panel Analysis of Developed and Developing Countries
}

\author{
Yahyaoui Ismahene ${ }^{1}$
}

Received: 20 April 2020 / Accepted: 30 May 2021/Published online: 21 July 2021

(c) The Author(s), under exclusive licence to Springer Science+Business Media, LLC, part of Springer Nature 2021

\begin{abstract}
The purpose of this paper is to examine the effect of infectious diseases on trade and economic growth in 88 countries (44 developed countries and 44 developing countries). Annual panel data from 1996 to 2018 are examined using the Pedroni panel cointegration test in order to check the existence of a long-run relationship; FMOLS, DOLS, and the VECM techniques to detect the causality direction. The following findings are established. First, in the long run, infectious diseases are more destructive on economic growth in developing countries than in developed countries. Second, infectious diseases have a negative and significant influence on the trade openness, but more intensively in developed countries than in developing countries. Finally, using the VEC model, our results demonstrate that the short run causality between diseases, economic growth, and trade openness is unidirectional running from infectious diseases to trade and economic growth. However, in the long run, there is bidirectional Granger causality among the running variables. Based on these results, government makers should concentrate more on the healthcare delivery in order to realize higher rates of economic growth and trade.
\end{abstract}

Keywords Infectious diseases · Trade $\cdot$ Economic growth - Developed countries · Developing countries

\section{Introduction}

Health is an economic indicator of development. It describes the physical, social, and emotional well-being of a human being (Trudel-Fitzgerald et al., 2019; WHO, 2013). A healthy population means valuable human capital and a productive and active workforce (Bloom \& Canning, 2000; Bloom et al., 2004; Jack \& Lewis, 2009). Several researches indicate that better health positively affects work, wages, consumption, investment decision, etc. (Lindert, 2004; Paul \& Gruber, 2002; Strauss \& Thomas, 2008).

\footnotetext{
This article is part of the Topical Collection on Enhancing the Adaptability of Family Businesses to the Knowledge-based Economy

Yahyaoui Ismahene

Asmahen.yahyaoui@gmail.com

1 University of Sousse, Sousse, Tunisia
} 
The health risks of disease outbreaks and epidemics, and the resulting fear and panic, lead to various risks to the economy. First, there is the risk of costs to the health system, both public and private, of medical treatment of infected people and control of the disease. A virulent episode can overwhelm a health system: it limits its ability to provide routine care and, therefore, worsens the situation. Beyond the shocks to the health sector, an epidemic forces both the sick and their caregivers to take time off work or be less efficient, which undermines productivity (Cole \& Neumayer, 2006; Dhanaraj, 2014; Genoni, 2012). Fear of infection can lead to social isolation, so wages will be lower (Schultz \& Tansel, 1997) and the consumption increases (Rakib, 2019). Also, it can conduct to the closure of schools. So, health shock is negatively related to education (Sun \& Yao, 2010).

The epidemic is also hitting trade openness in affected and nonaffected countries. The deficit in the trade balance resulting from the outbreak of the disease in these countries continues to widen following the decrease in imports and exports. In fact, the fear of spreading a disease, even if it is relatively contained, can cause trade to decline.

The primary cost of infectious disease is loss of life. Infectious diseases have killed more people than famine, war, accidents, and crimes together. According to Lopez et al. (2006), five infectious diseases (lower respiratory infections, HIV, diarrheal diseases, tuberculosis, and malaria) were among the top ten global causes of death. According to the World Health Organization (WHO), infectious diseases caused $32 \%$ of deaths worldwide, $68 \%$ of deaths in Africa, and $37 \%$ of deaths in Southeast Asia (WHO, 2018). These diseases account for $90 \%$ of the health problems worldwide and kill about 14 million people annually, $90 \%$ of whom are from the developing world.

In order to moderate the influence of imported infections on local transmission and avoid mortality in returning travelers, some countries, such as Saudi Arabia and Thailand, access to prompt diagnosis and treatment along borders with endemic regions; also, they extend free access to noncitizens at existing health facilities, such as access to curative and preventive health services for Angolans in Namibia (Coleman et al., 2013; Ministry of Health of Angola 2010). In addition, in lowmalaria endemic or receptive malaria-free regions, it is essential to ensure that primary healthcare staff members are trained to suspect, correctly diagnose, treat, and rapidly report malaria cases. This important effort requires allocation of resources for continual supervision, training, and monitoring of health providers in both the public and private sectors (Hugh et al., 2015).

No one can dispute the role of the laws that play a capital role in prevention and control of infectious diseases such as HIV, corona, cardiovascular disease, diabetes, and respiratory disease. In fact, legal interventions such as taxation, marketing restrictions, and bans on smoking in public places have changed culture and behavior. Also, those legal interventions reduce the infectious diseases and their contagion (WHO, 2017).

This study designates several achievements and contributions to date in this line of research and goes on to apply a new panel technique to re-examine, on first hand, the relationship between trade and infectious diseases, on the other hand, the relationship between economic growth and economic growth. Therefore, our paper 
differs from the previous literature and makes at least three contributions. First, previous studies neglect the long term influence of diseases on macroeconomics variables. Indeed, to the best of our knowledge, the current article is the first attempt to employ FMOLS and DOLS models in order to investigate the long-term relationship between trade, economic growth and infectious diseases. Second, previous studies have not looked at the impact of infectious diseases on trade openness. In the context, only Kambou et al. (1993) examined the impact of HIV on exports. In this case, I examine the influence of diseases on trade openness. Third, to our knowledge, the study is the first to establish the long-term and short-term causality using the VECM model.

The rest of the paper is organized as follows: The second section briefly reviews the literature discusses the causality-link between trade, diseases, and economic growth. The third section describes data, source, and methodology used in our analysis. The fourth section presents empirical results, followed by the conclusions and policy implications being provided in the fifth section.

\section{Literature Review and Hypotheses}

To better understand the impact of infectious diseases on economic growth, it is essential to know the channels through which health affects economic growth (Weil, 2014; Bloom et al., 2019). Generally, good health has, on the one hand, a positive effect on the supply of productive labor and therefore higher incomes (Bloom et al., 2020). On the other hand, good health can increase high life expectancy and decrease morbidity which can increase schooling and therefore the accumulation of human capital (Bleakley, 2007, 2010; Boucekkine et al., 2002a, b; Cervellati \& Sunde, 2005). Also, health positively affects savings and investment (Alsan et al., 2006; Bloom et al., 2007). Similarly, health implies a decline in fertility due to a decline in precautionary fertility and higher opportunity costs for children, which can then trigger a take-off in investments in education and the emergence of a demographic dividend (Bloom et al., 2017, 2020; Cervellati \& Sunde, 2011; Klasing \& Milionis, 2020).

Generally, countries with poor health are trapped in a Malthusian stagnation balance. In such a context, negative health shocks due to an epidemic can have strong negative effects on economic growth by perpetuating stagnation or pushing the economy into a poverty trap (Chakraborty et al., 2010; Lagerlöf, 2003; Momota et al., 2005).

In order to examine the theoretically connection between trade and diseases, the majority of studies focused on the impact of trade on health. In this case, Fatima et al. (2020) claimed that trade openness is a part of globalization and it has an impact on health through various set of channels (economic infrastructure, economic development, economic insecurity, inequality...). Also, Woodward et al. (2001) showed that trade affects health directly and indirectly. In addition, others studies confirm that trade increase the infant mortality (Pham, 2016), spread of infectious diseases (Kawachi \& Wamala, 2006). 
However, the previous researches neglect the direct impact of infectious diseases on trade openness that represents one of my three contributions.

The link between infectious diseases and economic growth has been extensively studied in recent years. This impact differs from country to another. In fact, for developing countries, using the ordinary least square and two stages least squares estimators, Bonnel (2000) examined the impact of HIV/AIDS on economic growth in Africa during the period 1990-1997. He concluded a significant negative association between these two variables with an estimated average annual growth reduction of $0.7 \%$. In addition, using a cross-section growth framework in sub-Saharan Africa, McCarthy et al. (2000) concluded a negative relationship between higher malaria morbidity and the economic growth measured by the growth rate of GDP per capita with an estimated average annual growth reduction of 0.55 percent. Similarly, Dauda and Olaniyan (2017) reported a declining influence of HIV/AIDS on economic growth in the case of Nigeria. Also, Abdulsalam (2010) examined the sectoral impact of HIV/AIDS on the Nigerian economy. He suggested a decreasing effect of the disease on output, especially in the agriculture and manufacturing sectors; however, its influence on output in the oil and gas sector in some cases is positive.

A wealth of studies reflecting the causal relationships between malaria and economic growth have been conducted. Gallup and Sachs (2000) discovered that malaria increases have a negative impact on economic activities at more than one percentage point a year. Similarly, Qureshi and Mohyuddin (2006) showed that malaria and hepatitis affect significantly and negatively the growth rate of GDP. Other studies such as McCarthy et al. (2000) confirmed that higher malaria morbidity affects negatively and significantly the growth rate of GDP per capita in subSaharan Africa. In addition, Suhrcke and Urban (2010) showed a negative effect of cardiovascular diseases on subsequent economic growth in high-income countries over the period 1960-2000. Also, Garthwaite (2012) shows that restricted access to innovative pharmaceutical pain relief has led to a reduction in US labor supply. Bloom et al. (2003) showed that mortality reductions has a positive effect on labor supply, saving and investment in physical capital, especially in developing countries. In the same way, Boucekkine et al. (2002a, b) confirmed that mortality reductions increase the return to educational investments. Besides, Field et al. (2009) and Luca et al. (2018) concluded that working-age population's health is affected positively by low-intensity health interventions in developing countries where health status is low.

In addition, Fortson (2011) demonstrates that educational attainment is low in because of African countries higher levels of human immunodeficiency virus (HIV). Moreover, Aksan and Chakraborty (2014) showed that decreased child mortality in African countries has not led to a continuous fertility decline. Aksan and Chakraborty (2014) concluded that Africa's child mortality was restricted principally through medical treatment campaigns rather than through the eradication or prevention of infectious diseases.

However, Over (1992) showed that infectious diseases affect positively the economic growth. In fact, he concluded that AIDS epidemic reduced the population growth rate, so the growth rate of per capita income increased in any plausible economic model. Similarly, Young (2005) confirmed the positive influence of HIV/AIDS on per capita consumption in South Africa with rise of $1 \%$ in per 
capita consumption in South Africa as a result of HIV/AIDS. This positive relationship can be explained by the fact that in period of HIV/AIDS, the number of deaths increases, so the population decreases, then the per capita consumption rises. In the same way, Bureau for Economic Research (2006) showed the positive relationship between AIDS and real per capita GDP growth. Indeed, the real per capita GDP growth during the AIDS period is greater between 0.28 and $0.43 \%$ than that during the period without AIDS.

For the developed countries, Bloom et al. (2014) concluded that over an 18-year period, five categories of noncommunicable diseases (cardiovascular disease, cancer, chronic respiratory disease, diabetes, and mental health disorders) decrease labor supply and capital accumulation in China and India. Furthermore, Suhrcke and Urban (2010) shows a negative impact of cardiovascular diseases on economic growth in developed countries over the period 1960-2000. In the same way, Hyclak et al. (2016) concluded that cardiovascular diseases affect negatively the economic growth in the case of Spain between 2000 and 2012.

For the relationship between trade and health, Yach and Bettcher (1998) showed that trade could have a positive effect on health status. Indeed, the diffusion of technologies to poor or remote communities and nations could positively affect health. Thus, according to Yach and Bettcher (1998), information technologies play an important role in economic and social development, especially in developing countries.

Furthermore, Derek et al. (2000) showed that trade can negatively influence health through the extensive promotion and marketing of harmful products, namely tobacco. Also, international trade and travel increase the risk of crossborder spread of infectious diseases.

Herzer (2017) showed a positive relationship between trade and life expectancy. In fact, Herzer (2017) confirmed that trade is responsible for $12 \%$ of the annual rise in life expectancy, especially in lower-income countries. In addition, using cross-country data, Owen and Wu (2007) and Stevens et al. (2013) showed that trade has a positive impact on health, especially on infant mortality and life expectancy, especially in developing countries.

Others studies show that trade affect indirectly health by its impacts on environmental outcomes (air, water pollution, CO2 emissions, etc.). In this context, Chay and Greenstone show that during the recession of the 1980s, especially with the decline in manufacturing production, total suspended particulates positively affect infant mortality. In the developing country context, Arceo et al. (2015) showed that the neonatal and infant mortality can be reduced by the stringent air quality regulations in Mexico City. In the same way, Ebenstein (2012) concluded the existence of a positive relationship between water pollution and digestive cancers in the case of China.

For the impact of trade on obesity, Miljkovic et al. (2015) showed that trade has a positive impact on obesity. This impact is larger in developing countries than in developed countries. In the same way, Blouin et al. (2009) confirm that trade liberalization, by decreasing the prices of unhealthy foods, affect positively and significantly obesity and chronic diseases in many developing countries. 
However, few of studies examine the influence of health on trade. For example, Kambou et al. (1993) found that disease affect negatively exports, so disease has a negative impact on openness. Also, Ploetz et al. (2015) show that diseases are serious obstacles to exports and smallholder production.

So, the following hypotheses are formulated:

Hypothesis 1: Infectious diseases affect negatively economic growth in long run.

Hypothesis 2: Infectious diseases affect negatively trade openness in long run. Hypothesis 3: There exists a bidirectional causality relationship between economic growth and infectious diseases.

Hypothesis 4: There exists a bidirectional causality relationship between trade openness and infectious diseases.

\section{Conceptual Framework}

The World Development Report (1993) examined the relationship between health and economic growth, employing a sample of seventy countries over the period 1960-1990. Their results suggest that health is an important factor of economic performance found that health status is a highly significant predictor of economic performance. Similarly, Strauss and Thomas (1998) showed a strong association between health status measured by the height and the body mass index and income in low income, especially in manual jobs requiring more strength. In addition, Bloom et al. (2003), and Bloom and Fink (2014) point out that the health status may be a very important determinant of the growth rate of the gross domestic product.

Microlevel studies have focused on the impact of health status and a particular disease on economic growth.

In this context, AIHW (2010) defined "A disease" as a physical or mental disturbance involving symptoms, dysfunction, or tissue damage. The human body can be affected by several diseases, ranging from common colds to cancers. Infectious and chronic diseases are the two main categories of diseases that can lead to poor health. In this work, we are interested in infectious diseases which can be defined as diseases caused by pathogens. The spread of these diseases from person to person is mainly through air, food, water, inanimate objects, and insects or by direct or indirect contact with an infected person. By way of example, there may be mentioned influenza, malaria, and the human immunodeficiency virus (HIV).

Infectious diseases in country can be measured by different measures such as the number of people affected by the disease and also by the number of deaths caused by disease. In fact, counting the people with disease and the number of deaths caused by diseases is an important basic measure of disease frequency that is essential to detecting trends or the sudden occurrence of a problem, such as an epidemic. Simple counts of the number of diseased people are also important to public health planners and policy makers for assessing the need for resources in a population. Also, when measuring disease frequency, proportions and rates are very helpful when comparing groups, because they relate the number of people with disease to the size of the 
population in which they occur. Prevalence and incidence are the two fundamental measures of disease frequency.

\section{Data, Source, Descriptive Statistics, and Methodology}

\section{Data and Source}

This study used a panel data of 88 countries (44 developed countries and 44 developing countries (Appendix 1) of 20 years (1999-2018) selected on the basis of data availability. In addition, we choose these countries have the most important number of deaths caused by the infectious diseases. This classification based on United Nations (2019).

The selection of the starting period was constrained by the availability of data.

To test the optimum relationship between economic growth and infectious diseases, this study used the empirical model (1).

$$
G D P_{i t}=\beta_{0}+\beta_{1} \text { diseases }_{i t}+\beta_{2} X_{i t}+\varepsilon_{i t}
$$

In this empirical model, GDP ${ }_{i t}$ is the annual growth rate of GDP per capita with

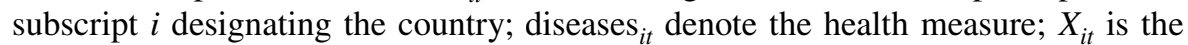
matrix of the $k$ control variables: Pop refers to the labor force which is proxied by the population growth (annual\%) (Ekanayake \& Chatrna, 2010); inf refers to inflation which is approximated by the GDP deflator (annual \%) (McGillivray et al., 2006); GOVEXP refers to general government final consumption expenditure ( $\%$ of GDP); INVST refers to the domestic investment measured by the gross fixed capital formation (\% of GDP) eit is the error terms.

To check the robustness of our results and appropriately and fully reproduce the influence of infectious diseases on economic growth and trade openness, we propose

Table 1 Description and sources of data

\begin{tabular}{|c|c|c|c|}
\hline \multicolumn{2}{|l|}{ Variables } & Description & Source \\
\hline \multicolumn{2}{|l|}{ GDP } & GDP per capita growth (annual \%) & WDI (2020) \\
\hline \multicolumn{2}{|l|}{ OPEN } & The sum of imports and exports of goods and services (\% of GDP) & WDI (2020) \\
\hline \multicolumn{2}{|l|}{ POP } & Population growth (annual \%) & WDI (2020) \\
\hline \multicolumn{2}{|l|}{ INF } & GDP deflator (annual \%) & WDI (2020) \\
\hline \multicolumn{2}{|l|}{ INVST } & Gross fixed capital formation (\% of GDP) & WDI (2020) \\
\hline \multicolumn{2}{|l|}{ GOVEXP } & General government final consumption expenditure ( $\%$ of GDP) & WDI (2020) \\
\hline \multicolumn{2}{|l|}{ FD } & Financial development domestic credit to private sector(\% of GDP) & WDI (2020) \\
\hline \multicolumn{2}{|l|}{ FDI } & Foreign direct investment inflows (\%GDP) & WDI (2020) \\
\hline \multirow[t]{3}{*}{ Diseases } & Malaria & No. of deaths-malaria (both sexes) & WHO (2020) \\
\hline & IID & No. of deaths-intestinal infectious diseases (both sexes) & \\
\hline & HIV & $\begin{array}{l}\text { No. of deaths-human immunodeficiency virus (HIV) disease (both } \\
\text { sexes) }\end{array}$ & \\
\hline
\end{tabular}


using three health measures: no. of deaths-malaria (both sexes); no. of deathsintestinal infectious diseases (both sexes); no. of deaths-HIV disease.

All variables are extracted from the World Development Indicators. However, the measures of diseases are extracted from the World Health Organization (Table 1).

In order to examine the effect of diseases on trade openness, we estimate Eq. (2).

$$
\text { OPEN }_{i t}=\beta_{0}+\beta_{1} \text { diseases }_{i t}+\beta_{2} Z_{i t}+\mu_{i t}
$$

where $\mathrm{OPEN}_{\mathrm{it}}$ refers to the trade opening that is measured by the sum of export and import relative to GDP(\%) (McGillivray et al., 2006; Gries et al., 2009); $\mathrm{Z}_{\text {it }}$ is the matrix of the k control variables: Pop refers to the labor force which is proxied by the population growth (annual\%); FD refers to financial development (Baltagi et al., 2009; Beck, 2002); FDI refers to the foreign direct investment (Omri et al. 2015); GOVEXP refers to general government final consumption expenditure (\% of GDP) (Taofik Mohammed, 2015); $\mu$ it is the error terms;

For the second model (Eq. 2), the specification of my model is ad hoc, insofar as it is not derived from the literature. The literature suggests a relationship between FDI and its determinants, but it does not offer a specific list of explanatory variables.

\section{Descriptive Statistics}

To gain a general understanding of the data, summary statistics describing the descriptive statistics of the different variables for each subgroup and also for the full panel are presented in Appendix 2. The main conclusion we can draw from this is that, on average, the highest level of GDP per capita growth (annual \%) is recorded in South Africa (32.99707). In addition, the highest levels of no. of deaths caused by the different diseases (intestinal infectious diseases, HIV, and malaria) are unregistered in South Africa in 2008 (39,282), 2013 (23,124), and 1999 (1096), respectively. For the general government final consumption expenditure ( $\%$ of GDP), Seychelles marked the highest value (47.19156) in 2002. In 2007, Bahrain unregistered the highest value of population growth (7.776022). For the consumer price index and the gross fixed capital formation (\% of GDP) in 2015, Venezuela and Cabo Verde unregistered the highest values in 2015 and 2011, respectively. Finally, Singapore had the most important value of trade openness in 2008 (437.3267).

However, the lowest value of GDP per capita growth (-18.17311) was unregistered in Venezuela in 2018. In addition, the lowest value of general government final consumption expenditure (\% of GDP) is 6.321636 which is unregistered in Guatemala in 1999. For the variable "population growth," Croatia unregistered the lowest value (-3.847671) in 2001. However, Angola and Tajikistan unregistered the lowest values of consumer price index $(0.684495)$ and gross fixed capital formation (\% of GDP) (6.295737), respectively. Finally, the lowest no. of deaths caused by the different diseases (intestinal infectious diseases, HIV disease, and malaria) are zero for every country especially in the first stages of the epidemic. 


\section{Methodology}

The main objective of this paper is to test whether there is a long-run relationship and dynamic causal between infectious diseases and economic growth, firstly, and between infectious diseases and trade openness, secondly. In this case, we used a panel data of 88 countries (44 developed countries and 44 developing countries) of 20 years (1999-2018).

In this research, different estimation techniques were used to check the robustness of relation between economic growth, trade openness, and infectious diseases.

The researcher will try to find the long-run relationship between economic growth and diseases in the first hand, and between trade openness and diseases in the second hand. For finding this, firstly we will try to explore the statistical properties of the data; we start by checking the presence of a unit root by applying two unit root tests: LLC (Levin, Lin \& Chu) test (Levin et al., 2002) and IPS (Im, Pesaran, and Shin) test (SoIma et al., 2013). Secondly, we attempt to describe cointegration analysis using Pedroni $(1999,2000,2004)$ test. After that, we will estimate FMOLS and DOLS model (Vo \& Vo, 2017; Vo et al., 2019b) in order to extract the longrun relationship between all variables in both models (1) and (2). Finally, our study used VECM model (Pesaran et al., 1999) in order to examine the Granger causality between economic growth and diseases in first hand and between trade openness and infectious diseases in second hand.

\section{Empirical Results and Discussion}

\section{Long-Run Relationship}

In order to examine the stationarity and determine the integration level of the selected variables, we used two recently developed tests: the LLC test (Levin et al., 2002) and IPS test (SoIma et al., 2013). Findings reported in Appendix 3 points out the stationarity in first difference of the data.

In the next step, we examine whether a long-run relationship exists among the interested variables. We employed the Pedroni test. The testing results reported in Appendix 4 suggest that all series are cointegrated in both models (1) and (2). In other words, there exists a long-term relationship between the dependent variable and the independent variables in the proposed research model. Given the variables are cointegrated, a FMOLS and DOLS models (Vo \& Vo, 2017; Vo et al., 2019b) are estimated to investigate the long run relationship between trade, economic growth and infectious diseases. 


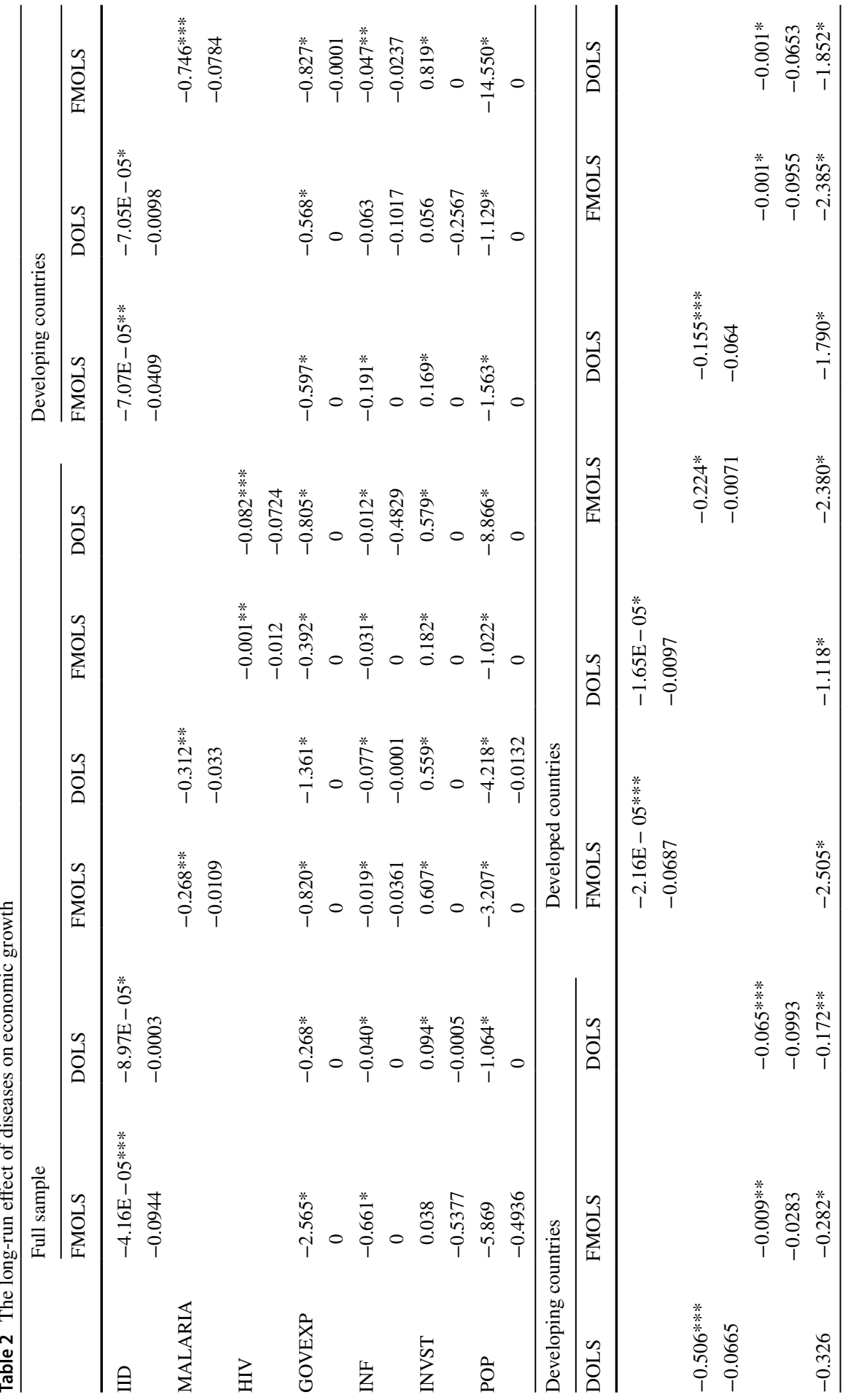




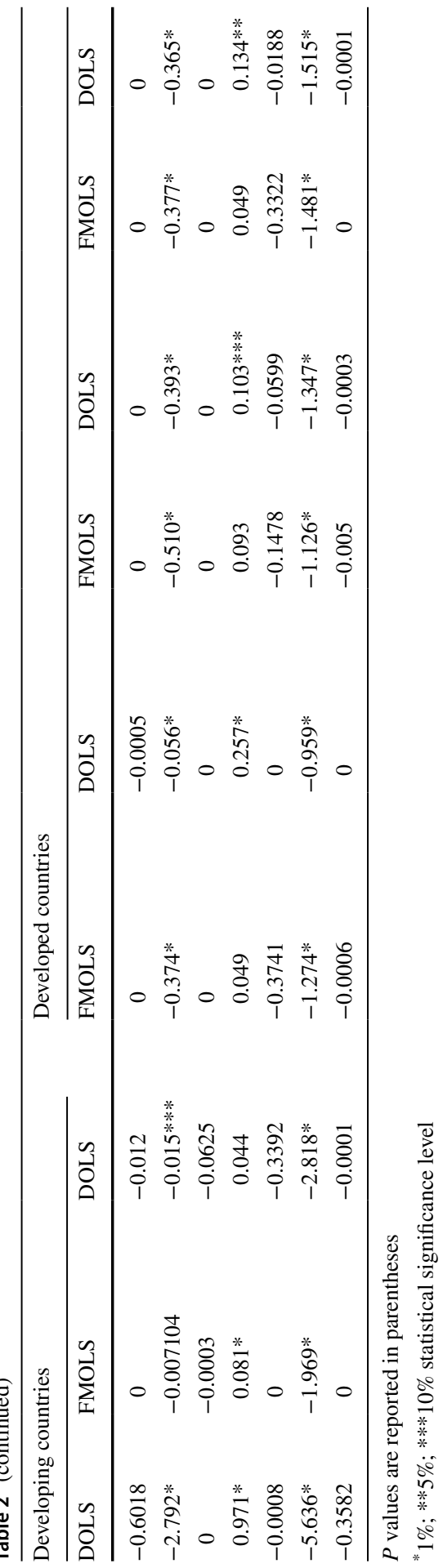




\section{Long-Run Impact of Infectious Diseases on Economic Growth}

Findings presented in Table 2 resume the results of long-run influence of infectious diseases on economic growth. Results reported in Table 2 show that the long-run effects are quite similar across the variables.

Findings presented in Table 2 show that infectious diseases deteriorate economic growth in the long run. Indeed, the coefficients of the different variables that measure the infectious diseases (Malaria, HIV, IID) are significant and negative. We conclude also that the coefficients in absolute value of the three diseases are more important in developing countries than in developed countries. In other words, in the long term, infectious diseases serves to decrease the GDP per capita of all countries, but more intensively so in developing countries than in developed countries. In fact, infectious diseases are less destructive on economic growth in developed countries because the health status in these countries is more developed.

Also, policy makers give great importance to health, yet health spending is greater than in developing countries. In addition, the greater negative influence of diseases in developing countries can be explained also by the poor health infrastructure and the migration of scientific talent from developing countries to developed countries due to weak wages.

Regarding the control variables, we find that in the long run, the government expenditure (GOVEXP) has a significantly negative effect on economic growth in all specifications in developed and developing countries. This negative relationship can be explained by the unproductive effect of government investment spending. The estimated coefficients of GOVEXP in the case of developing countries are less important than the coefficients in the case of developed countries. This is can be explained by the fact the amount in the one countries are lower in the developed countries.

For the variable population, the coefficients are negative and significant in our three samples (full sample, developing countries, and developed countries). Indeed, the high population growth rate has slowed the pace of economic development in the long run. Also, the rapid increase in population increases consumption needs. This increases consumer spending. The savings rate and capital formation therefore do not increase much. Hence, economic growth deteriorates in the long run. The high population growth worsens economic growth largely in developing countries than in developed countries because population growth rate is more important in developing countries.

For the variable inflation, it is significantly and negatively correlated with economic growth in the long run. This negative influence of inflation can be explained by the fact that when inflation increases, the investment decreases in the long run. So, we can say that investment is the main channel through which inflation reduces economic growth in the long run. Results reported in Table 2 demonstrate that the coefficients of the variable inflation are almost similar in all the samples studied. 


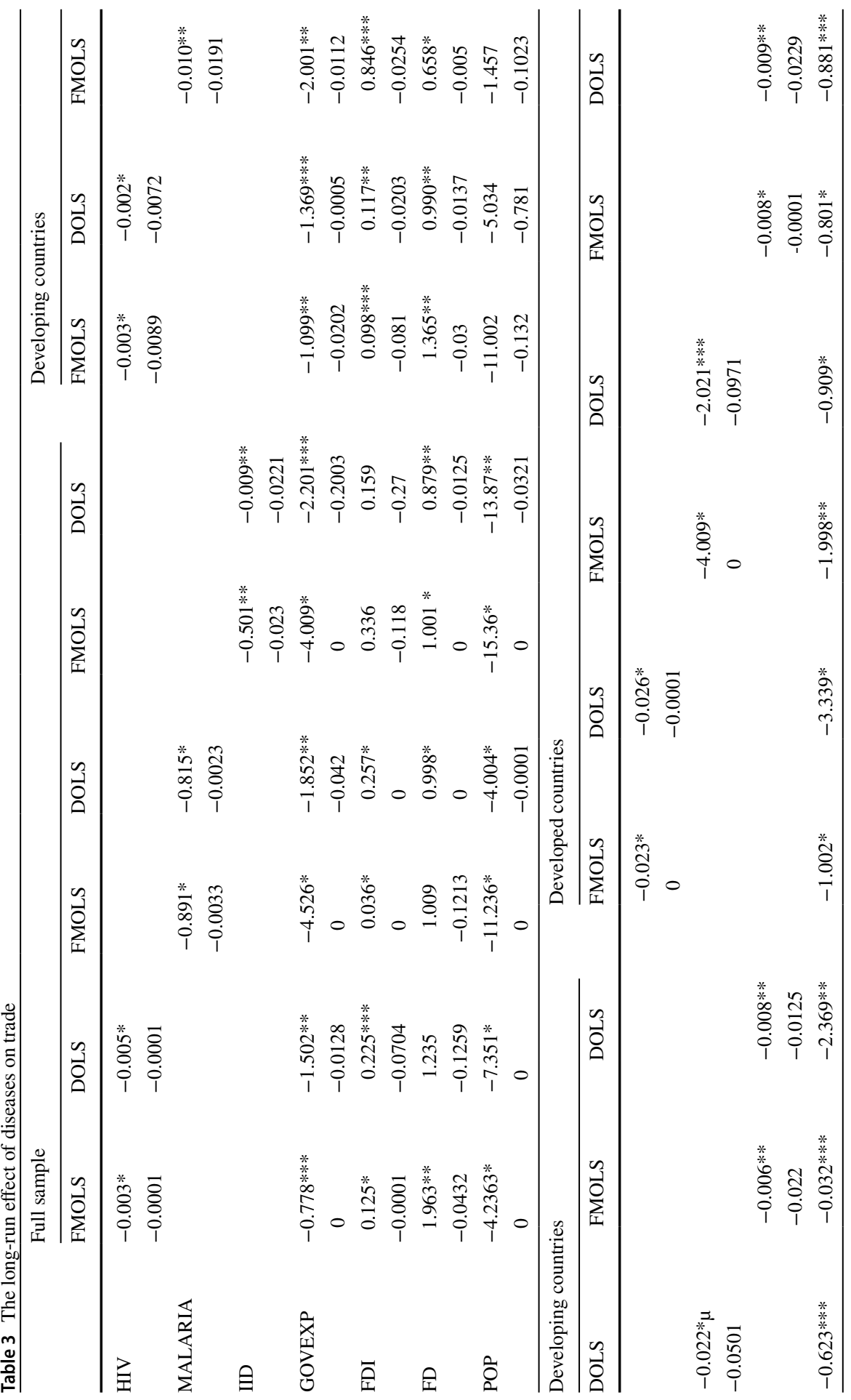




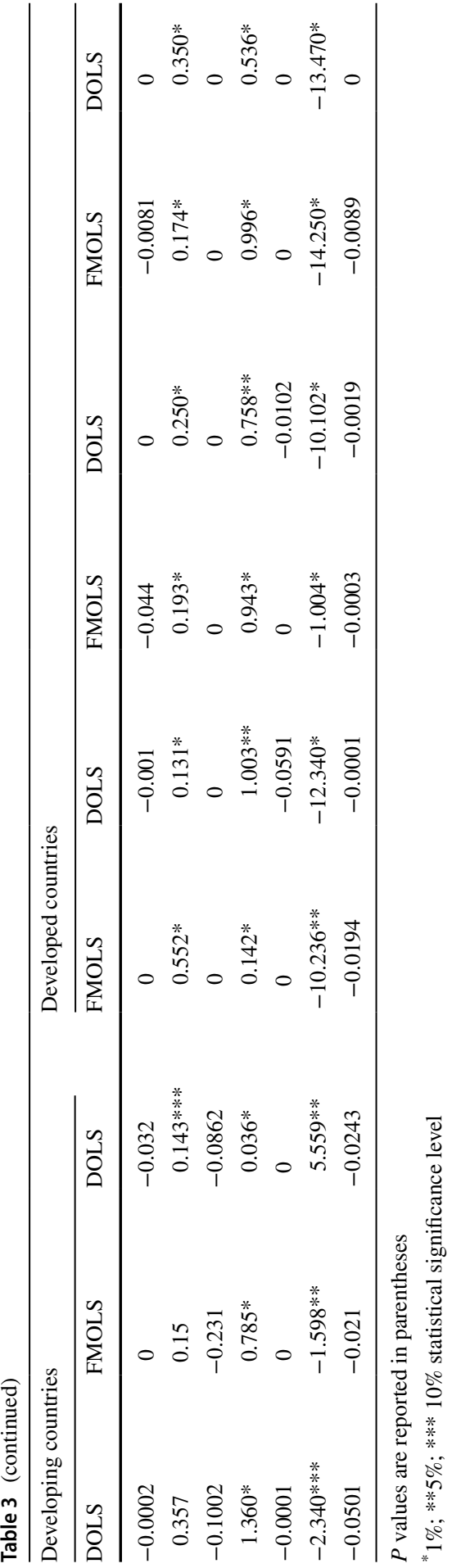


The coefficients of the variable investment are significant and positive. That means the investment ameliorate the GDP per capita in developing and developed countries.

\section{Long-Run Impact of Infectious Diseases on Trade Openness}

Findings presented in Table 3 resume the results of long-run influence of infectious diseases on trade openness. Regarding results reported in Table 3, we conclude that the different diseases (malaria, HIV, IID) have a negative and significant, in the long term, influence on the trade openness of all countries, but more intensively so in developed countries than in developing countries. This can be explained by the fact that the exports of developed countries are more important in developing countries. In fact, in period with diseases, the exports decrease, so the trade openness will be deteriorated.

In addition, financial development has a positive impact on trade openness in the long run. Indeed, the coefficient of the variable financial development is positive in all samples.

For the variable population, its coefficient is negative and significant in the majority of models. It is true that the population affects positively trade flows in the short term, because it can increase the quantity of labor, thus exports increase. However, in the long term, the increase in population makes it possible to decrease per capita income, which makes the citizen poorer, so production and exports decrease. In addition, the decline in per capita income also tends to lower demand for imports.

Results reported in Table 3 confirm that government expenditure has a negative and significant impact on trade openness in developing and developed countries. In fact, an increase in government expenditure leads to an increase in imports; this implies that it can lead to a deterioration of the trade balance.

Finally, for the variable FDI, its coefficients are positive and significant in the majority of our models. In fact, when the FDI increases, the production augments; this can lead to increase the exports and decreases the imports. Then, the trade openness will be ameliorated.

\section{Long-Run and Short-Run Causality}

In order to identify the direction of causality, the panel vector error-correction model (VECM) was used. As the variables are cointegrated, a VEC model (Pesaran et al., 1999) is pertinent.

This panel followed by the two-step procedure of Engle and Granger (1987) is employed to account for the long-run and short-run dynamic relationships. Shortrun causality is tested by the statistical significance of the partial F-statistics associated with the respective first differenced lagged independent variables. Long-run causality is determined by the statistical significance of the respective ECT (the error correction term) using a $t$-test. Before the estimation of the VECM model, 


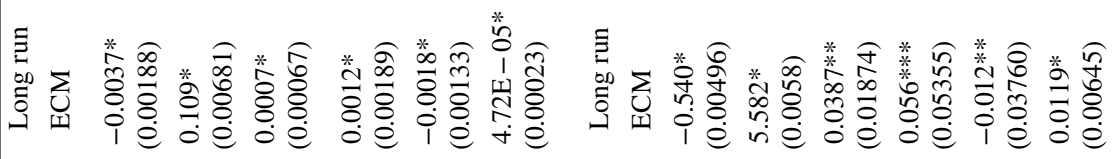

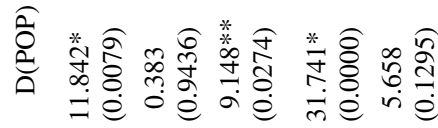

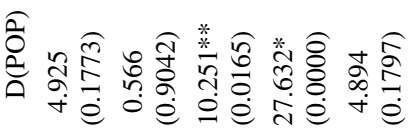

究

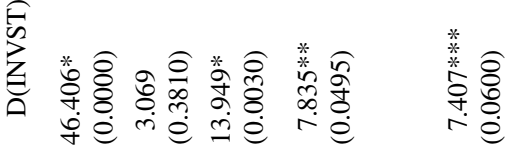

$\stackrel{0}{2}$

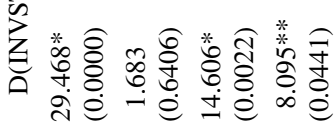

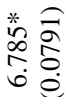

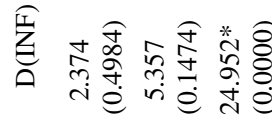

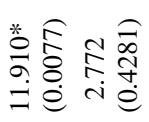

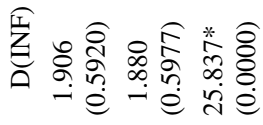

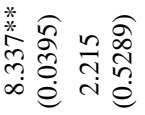

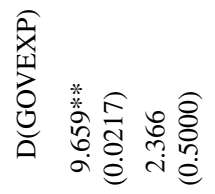

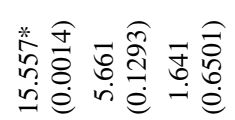

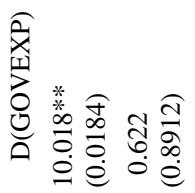

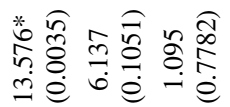

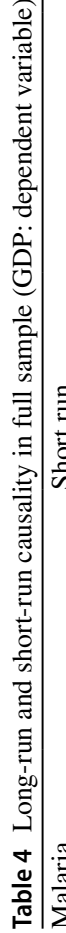

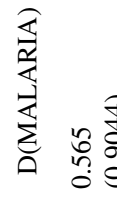

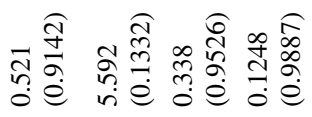

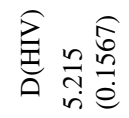

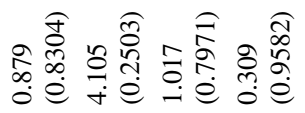

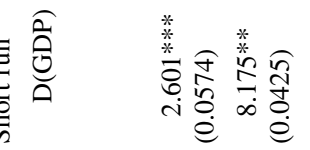

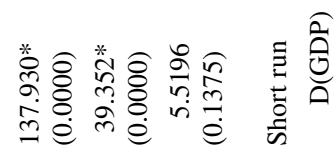

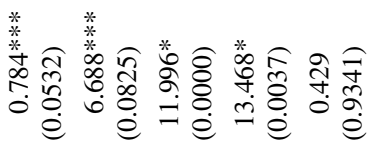

苍

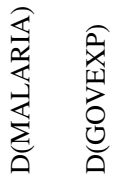

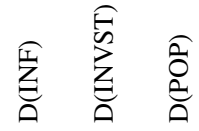

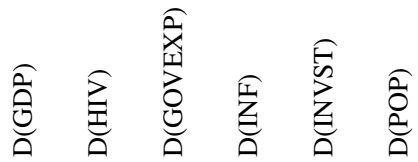




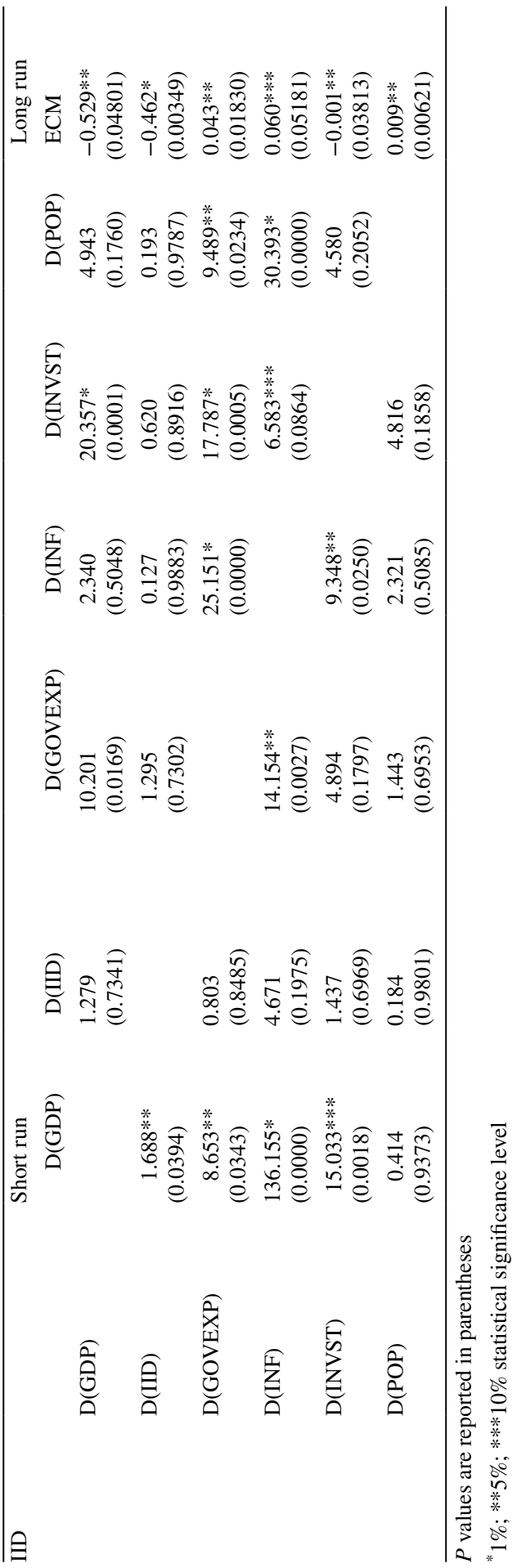




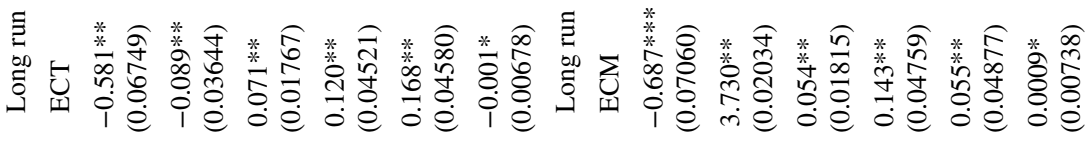

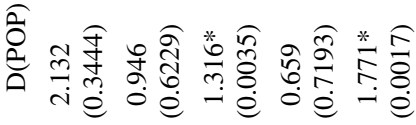

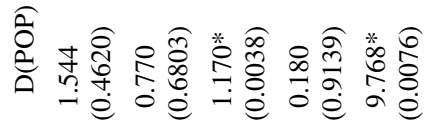

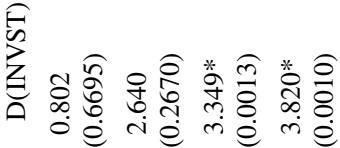

E

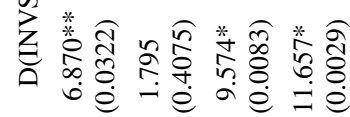

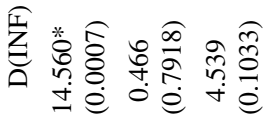

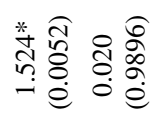

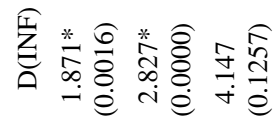

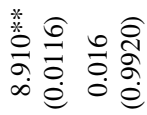

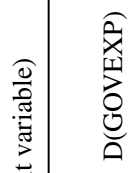

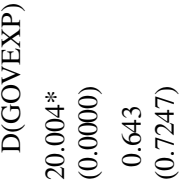

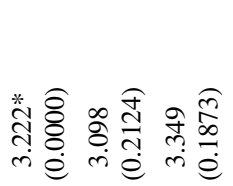

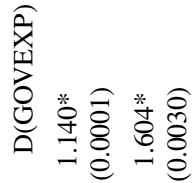

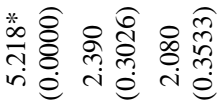

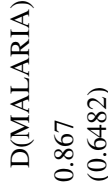

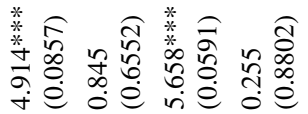

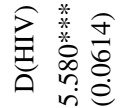

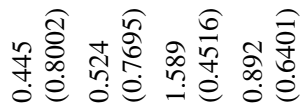

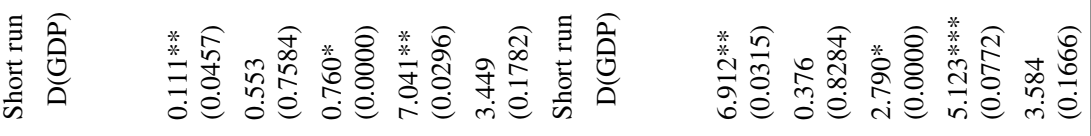

竞

Oิ) 


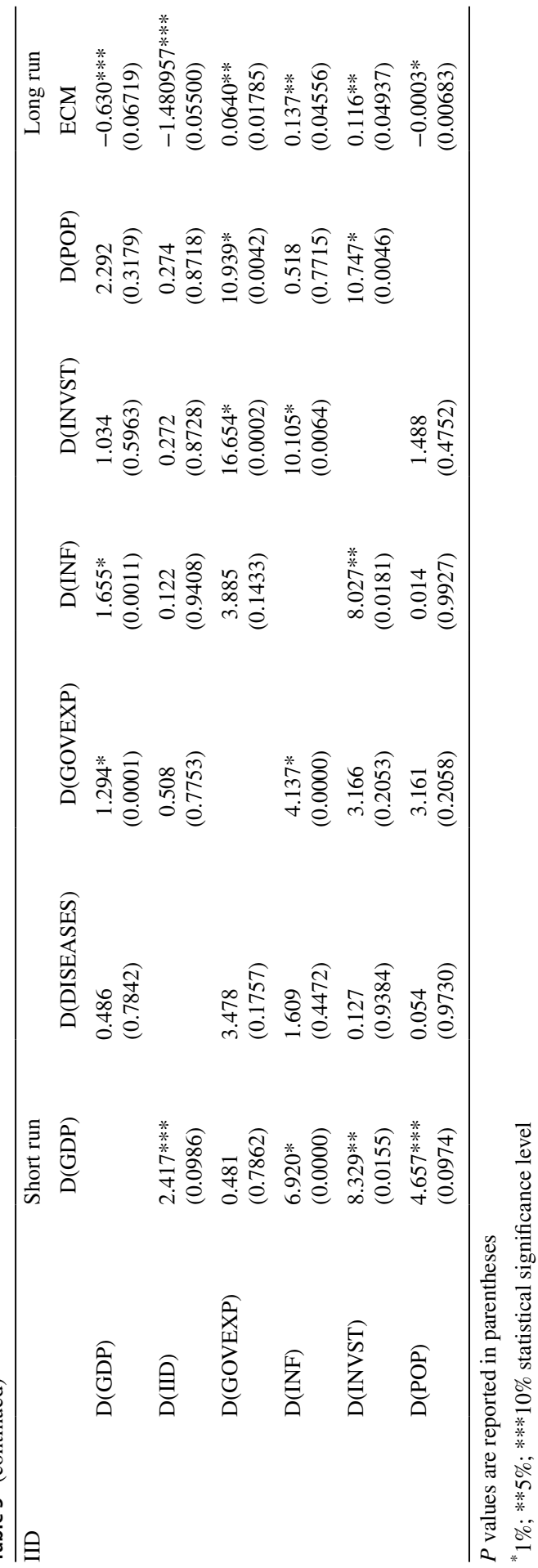




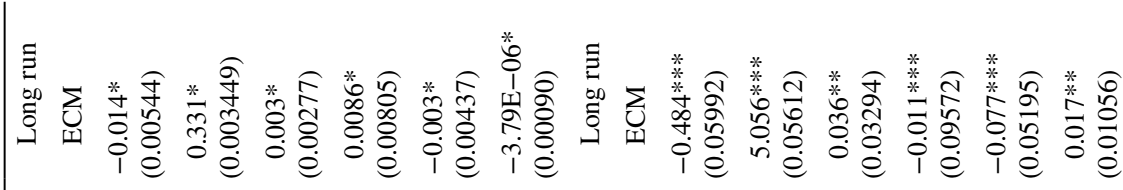

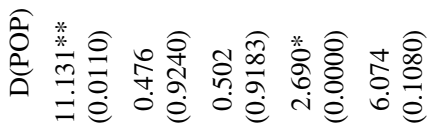

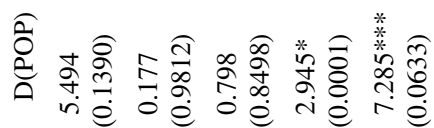

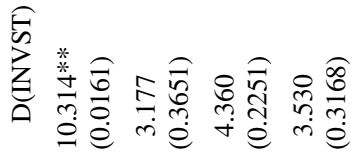

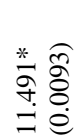

䆙

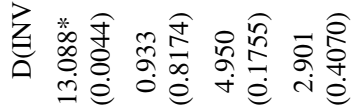

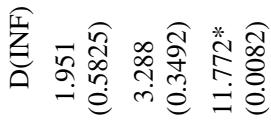

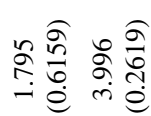

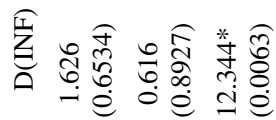

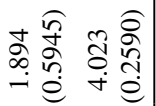

竞

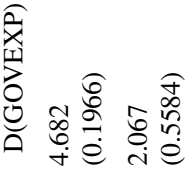

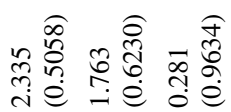

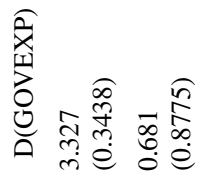

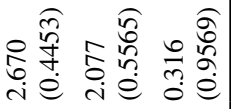

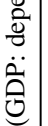

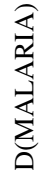

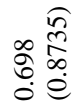

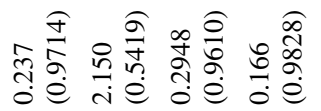

往

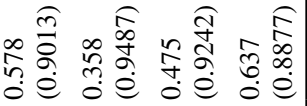

突

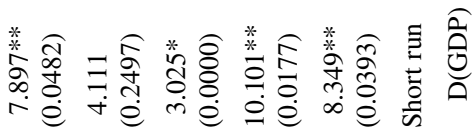

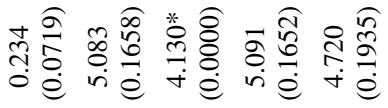

की

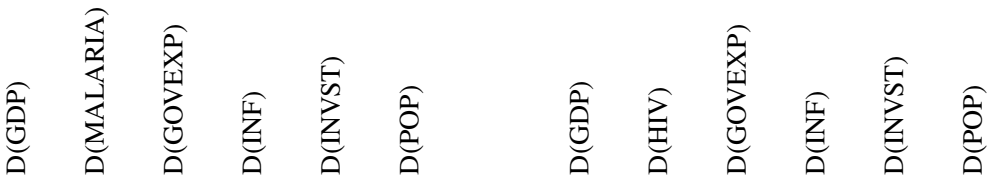




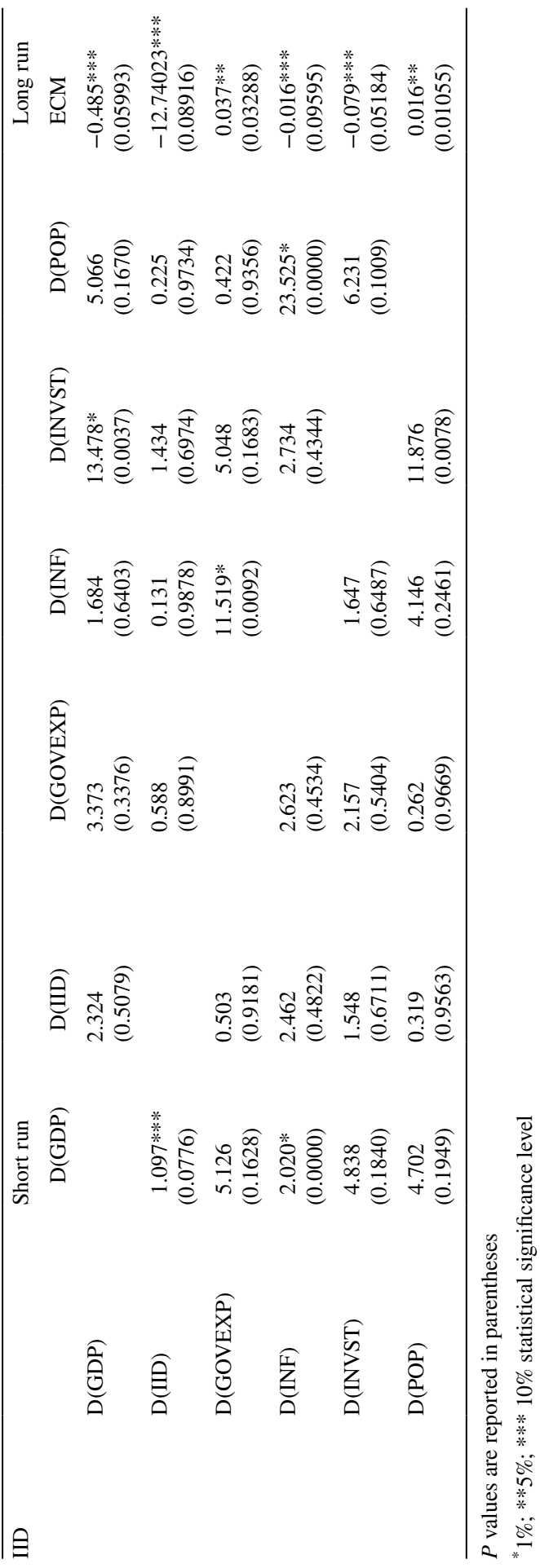




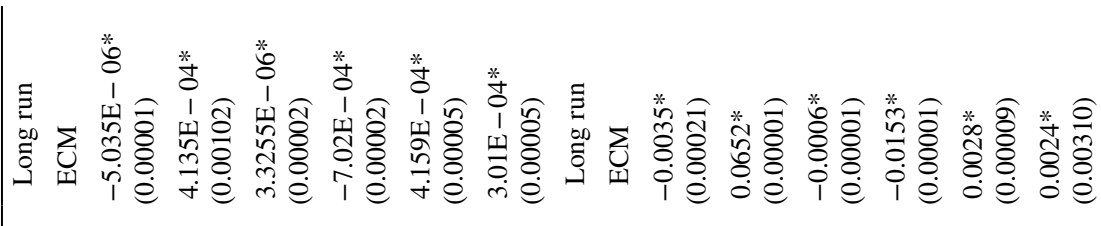

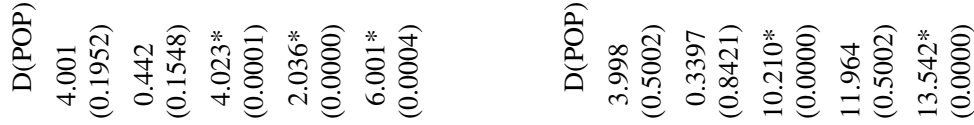

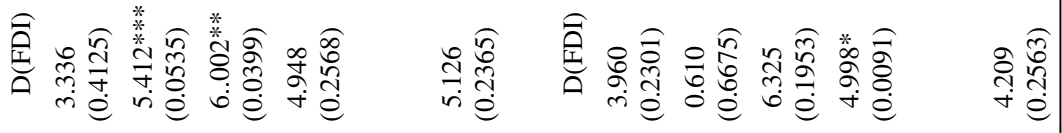

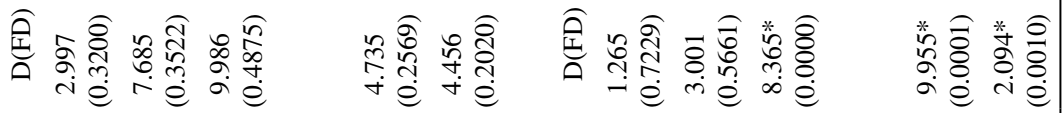

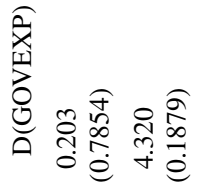

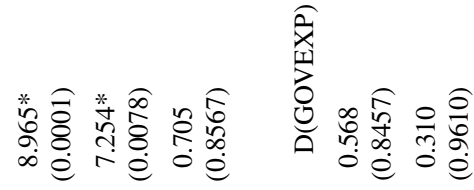

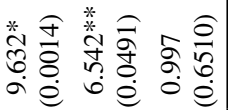

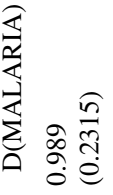

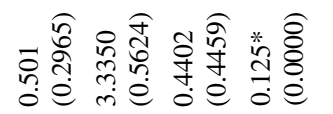

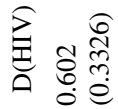

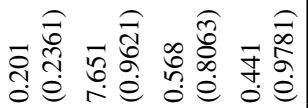

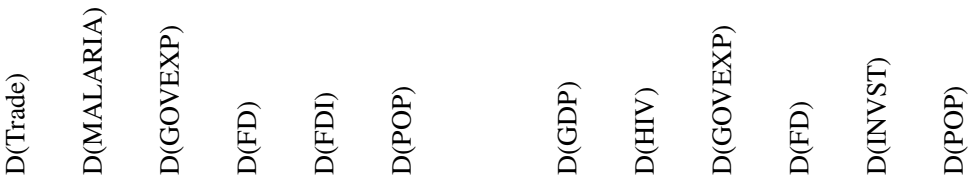




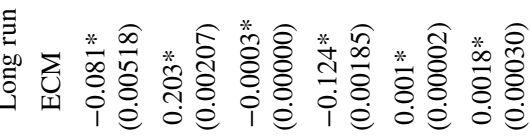

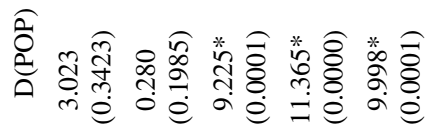

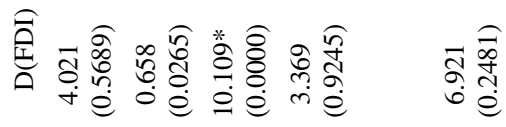

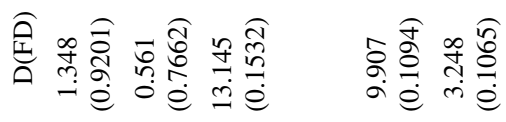

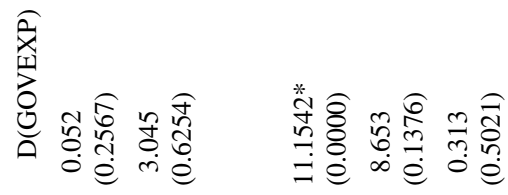

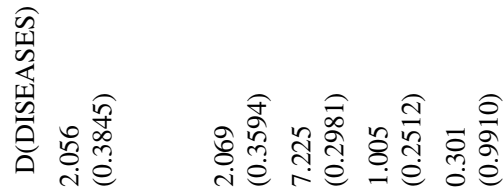

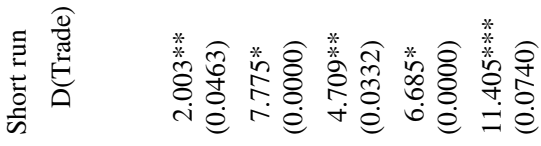

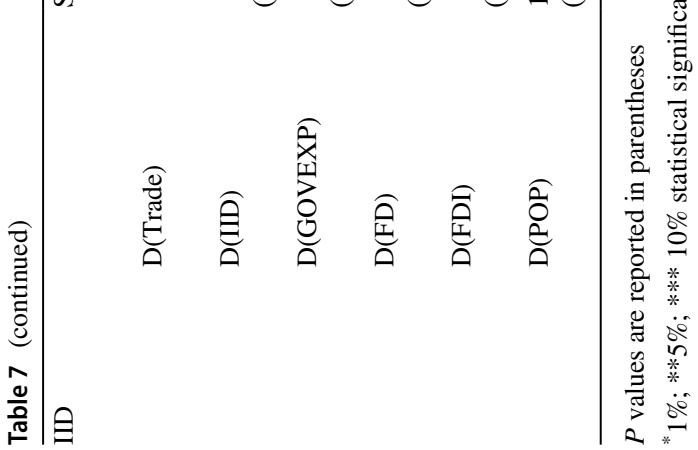




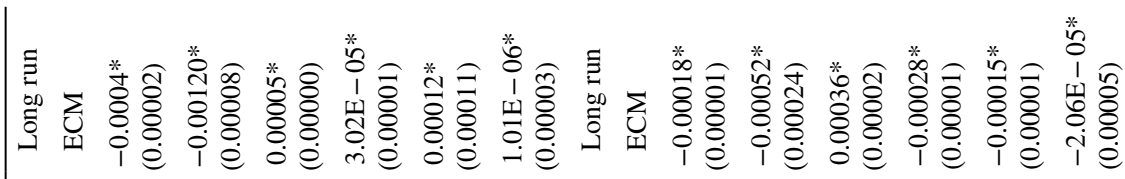

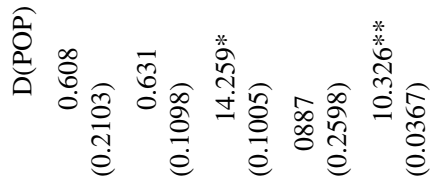

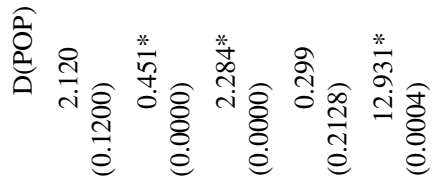

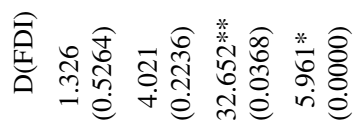

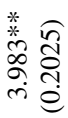

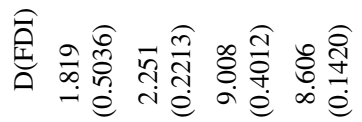

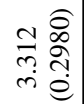

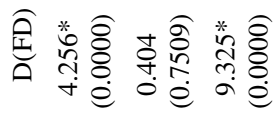

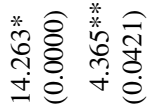

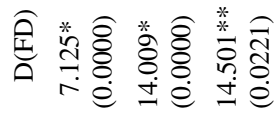

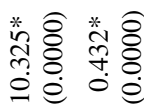

章

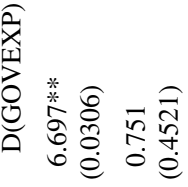

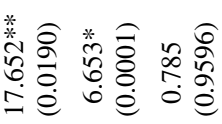

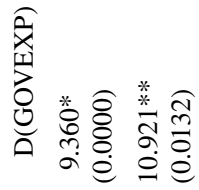

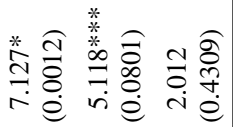

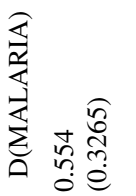

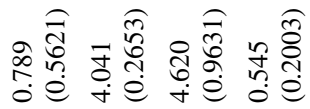

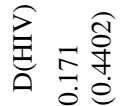

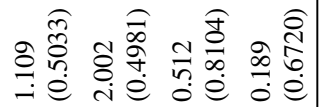

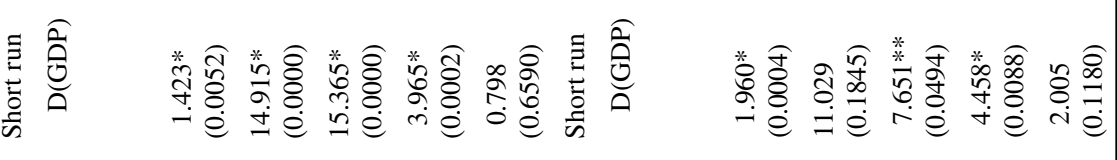

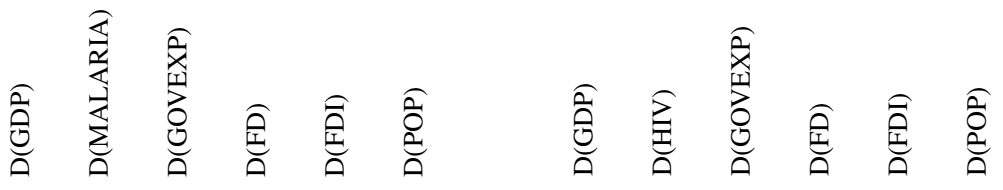




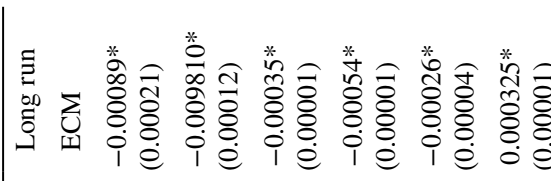

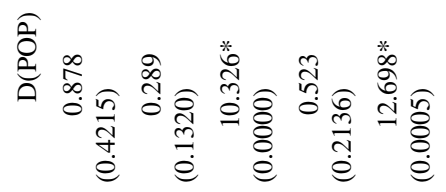

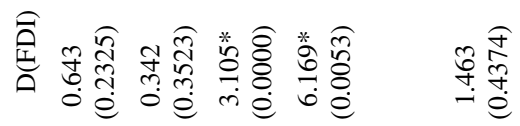

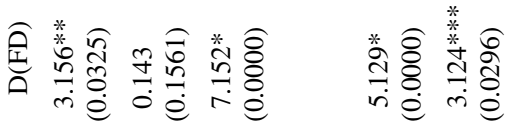

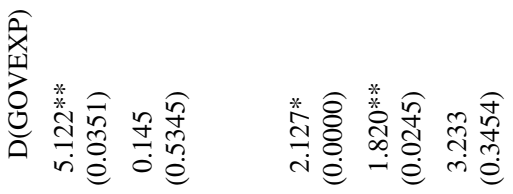

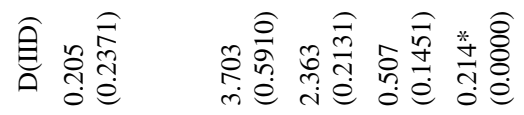

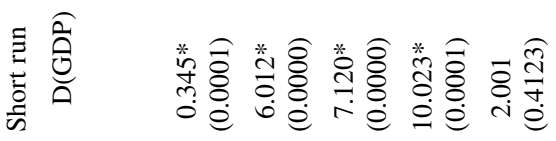

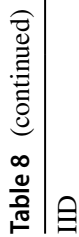

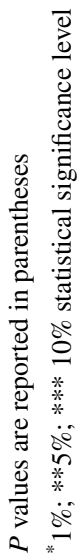




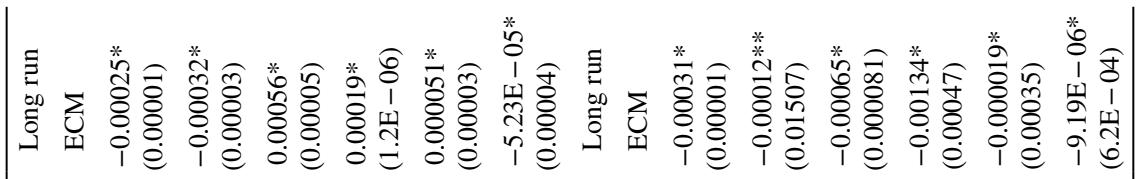

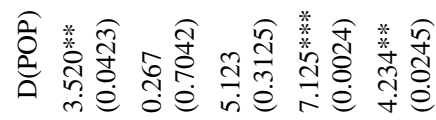

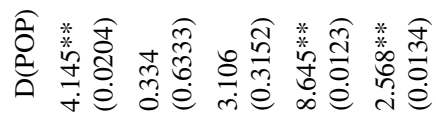

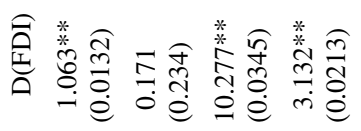

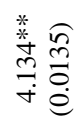

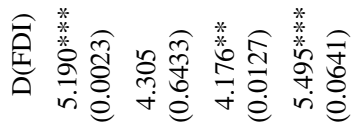

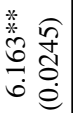

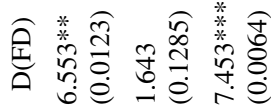

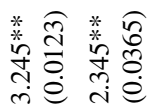

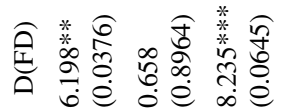

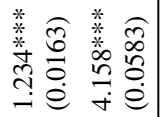

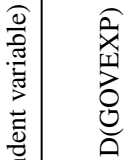

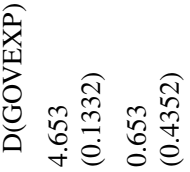

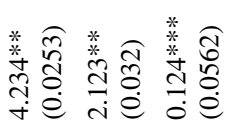

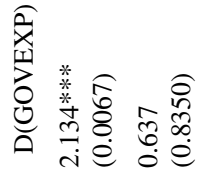

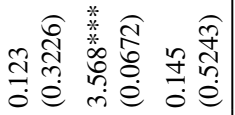

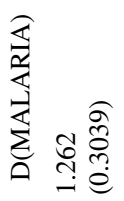

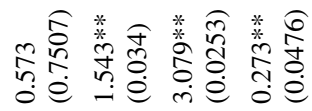

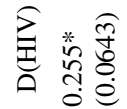

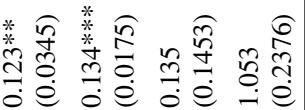

苍产 究

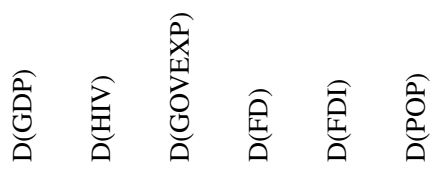




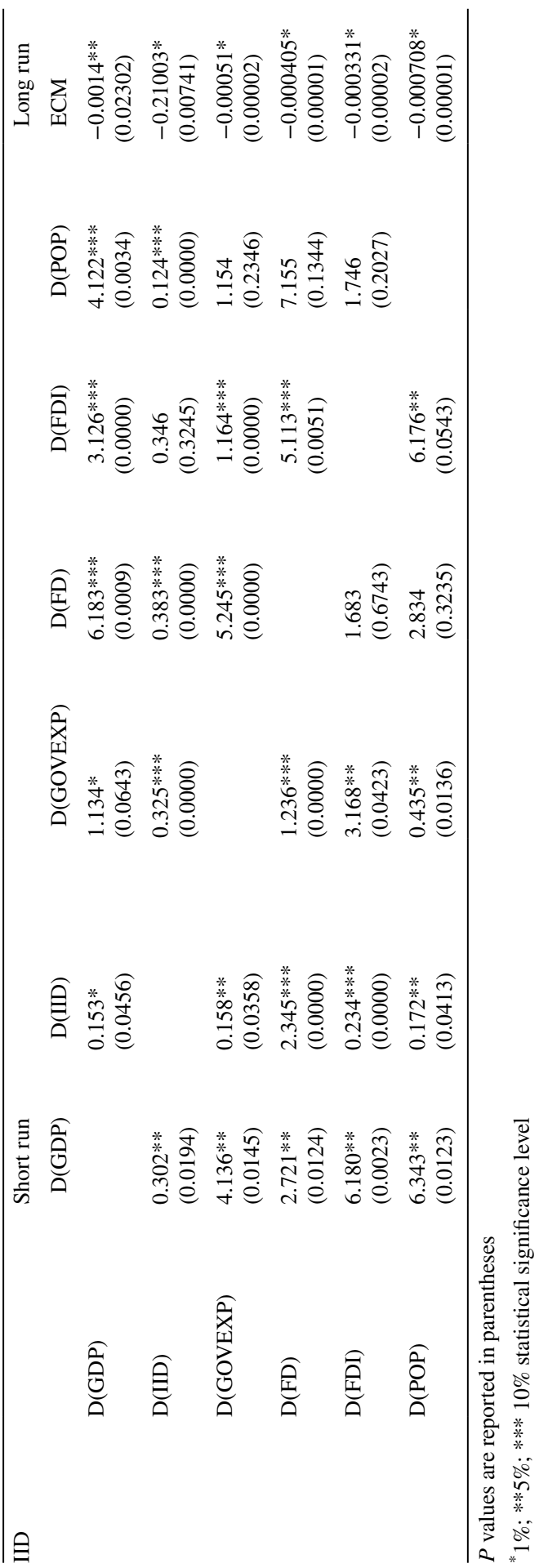


the number of lag is selected automatically through Schwarz information criterion (SIC).

The results of Granger causality between variables in Eq. (1), when GDP per capita is the dependent variable, are reported in Tables 4, 5, and 6. However, the results of Granger causality between variables in Eq. (2), when trade openness is the dependent variable, are reported in Tables 7, 8, and 9.

Results reported in Tables 4, 5, and 6 confirm that, in the short run, the causality between economic growth and different measures of infectious diseases (malaria, HIV, and IID) is unidirectional running from diseases to economic growth both in developing countries and developed countries.

In the long run, regarding the error correction term (ECT), 1\% level of significance is statistically significant which implies that economic growth shows a strong speed of error correction mechanism which drives back to long-run equilibrium.

This implies that in the long run, economic growth, disease, population, investment, government spending, and inflation have the same long-run behavior. Indeed, after the launch of ambitious strategies to improve health status, the management of government spending, population growth, and reaping the benefits of the process of sufficient domestic investment in the human aspect, these elements can generate the blessing of the resource abundance curse and thus improve the path of economic sustainability in the long run, both in developed countries and developing countries.

The highlights of the panel VECM regression reported in Tables 7, 8, and 9 revealed that there is a unidirectional causality effect running from different measures of infectious diseases (malaria, HIV, and IID) to trade openness both in developing countries and developed countries.

In the long run, the statistically significant estimate of ECT with a negative sign supports the long-run relationship among the variables.

\section{Conclusion}

The main objective of this study was to examine the long-run and causal relationships between infectious diseases and economic growth, on first hand, and between infectious diseases and trade openness, on second hand, for 88 countries over the period of 1999-2018. Furthermore, two homogenous subpanels have been considered based on the level of development of the sample countries (44 developed countries; 44 developing countries).

For this purpose, a panel cointegration framework has been deployed using the FMOLS, DOLS and VECM models. The results of the panel unit root tests suggest that all the variables are stationary at first difference I (1). Besides, the cointegration tests provide evidence of a long-term relationship between all the variables studied, whether in the first model where the relationship between economic growth and diseases was studied or in the second relationship where the relationship between trade openness and diseases was examined. 
The panel FMOLS and DOLS results indicate that the different measures of diseases (malaria, HIV, IID) have a negative and significant long-run effect on economic growth for the global, developed, and developing panels. However, it is important to mention that this negative effect of diseases is greater in developing countries than in the developed countries. This can be explained by the poor health infrastructure in developing countries. Also, the public health spending in these countries is very low compared to that in developed countries. In addition, this negative influence of diseases on economic growth is more important in developing countries can be explained by the migration of scientific talent from developing countries to developed countries due to weak wages.

However, the negative long-term influence of different diseases on trade openness is more intensively so in developed countries than developing countries. This can be explained by the fact the volume of exports is more important in developed countries.

The causality analysis indicates the existence of a unidirectional short-run effect between diseases and economic growth; and between diseases and trade openness for all specifications (full sample, developed countries, developing countries). Besides, in the long term, our empirical evidence shows the fact of a negative longrun relationship between diseases and trade openness; and between diseases and economic growth which means that the existence of curse mechanism implying that the diseases exerts a negative influence on the economic performance and trade openness.

It is crucial to appreciate the links between diseases, trade openness and economic growth so as to provide inputs to policymakers to help them formulate effective policies. The findings of this paper thus imply that a policy aimed at reducing the incidence of diseases will promote economic development and trade openness. In other words, government should concentrate more on the healthcare delivery in order to realize higher rates of economic growth and trade. So, if all the countries, developing or developed, of our study desire to create additional economic growth and expansive trade openness in the long term, decision makers must design sustainable and effective health policies to properly manage and control the diseases that may appear. In this context, political decision-makers should increase public spending on health, improve health infrastructure, encourage scientific talent not to immigrate by increasing wages. 


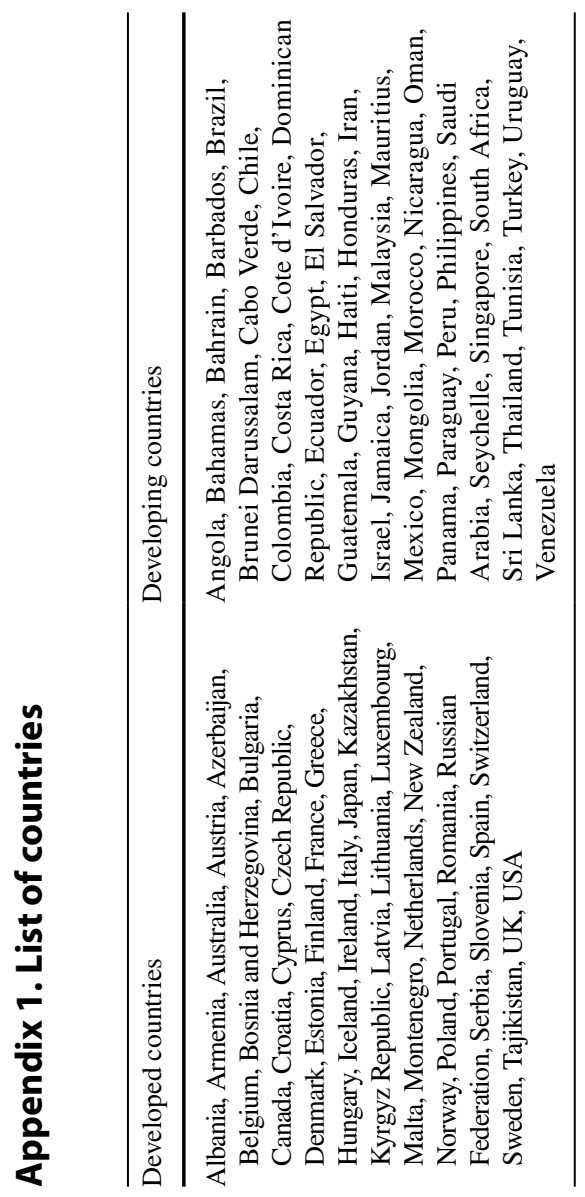




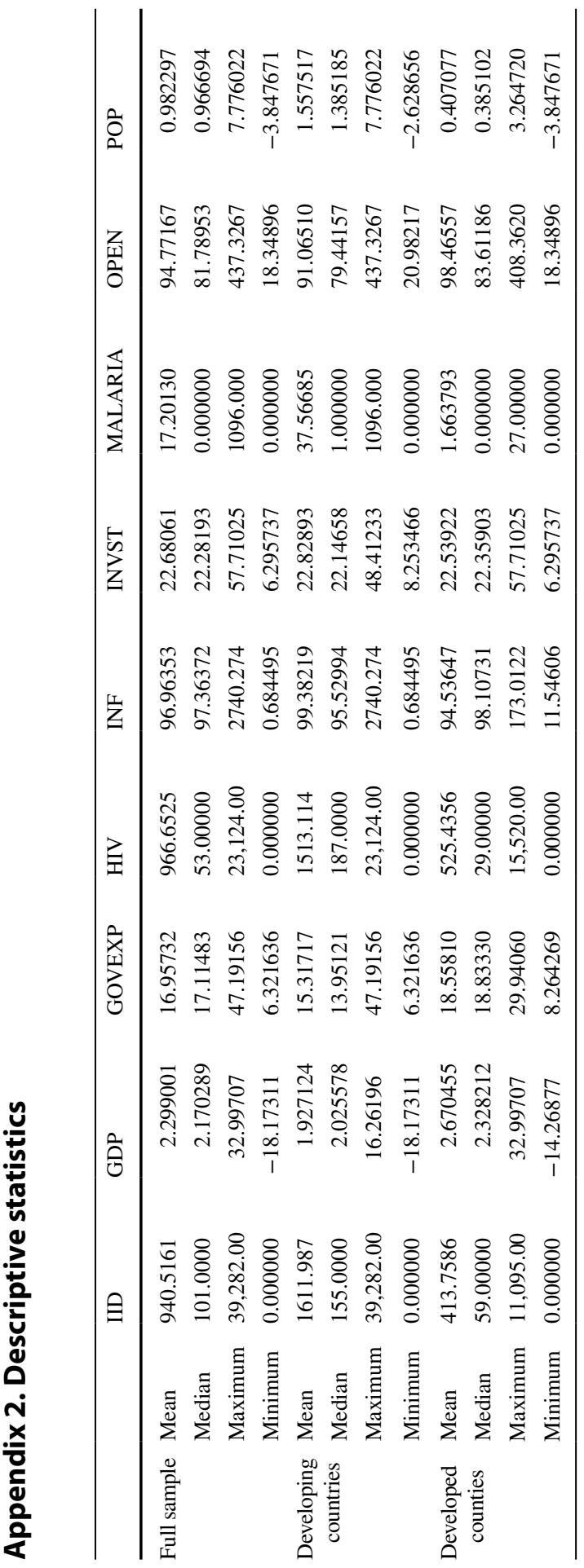




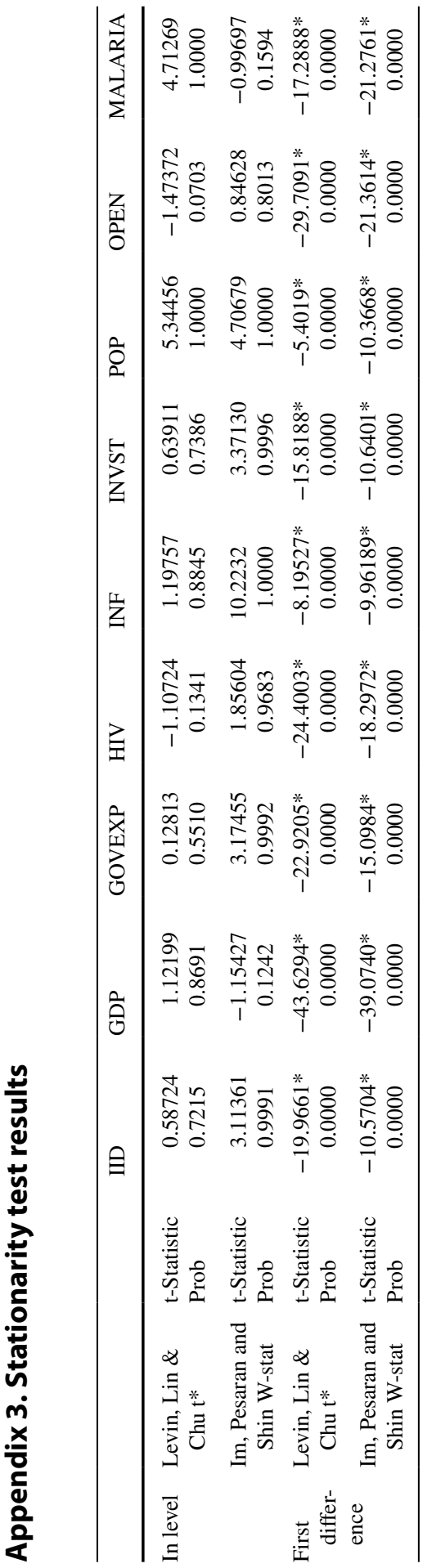




\begin{tabular}{|c|c|c|c|c|c|c|c|c|c|c|c|}
\hline & 을 & $\underset{\hdashline}{8}$ & ¿̊. & $\begin{array}{l}\text { İ } \\
\text { ป̀ } \\
\text { o }\end{array}$ & 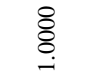 & 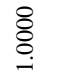 & \&̊ి & 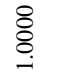 & 올 \& & $\begin{array}{l}8 \\
\vdots \\
0\end{array}$ & $\begin{array}{l}\text { ஃ. } \\
\text { مे }\end{array}$ \\
\hline \multirow[t]{2}{*}{$\begin{array}{l}\frac{s}{4} \\
\frac{a}{4} \\
\frac{1}{2}\end{array}$} & 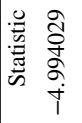 & 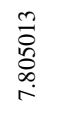 & 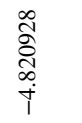 & $\begin{array}{l}\hat{0} \\
\hat{0} \\
0 \\
0 \\
1\end{array}$ & 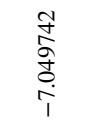 & 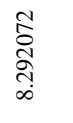 & $\underset{\substack{\infty \\
\infty \\
\infty}}{\stackrel{\infty}{\infty}}$ & 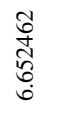 & 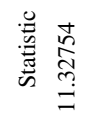 & $\begin{array}{l}\frac{m}{5} \\
\frac{5}{+} \\
\frac{a}{1}\end{array}$ & $\begin{array}{l}\vec{n} \\
\hat{n} \\
\tilde{n} \\
m\end{array}$ \\
\hline & 잉 & $\underset{\overbrace{}}{\circ}$ & ¿̊̊. & $\begin{array}{l}\infty \\
\stackrel{\infty}{\infty} \\
\stackrel{0}{0} \\
0\end{array}$ & 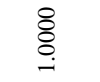 & 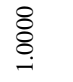 & \&̊̊. & 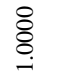 & 을 & $\begin{array}{l}8 \\
0 \\
0 \\
0\end{array}$ & 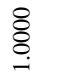 \\
\hline \multirow{4}{*}{ 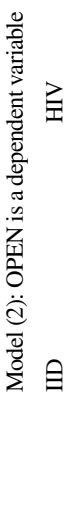 } & 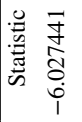 & $\begin{array}{l}\stackrel{+}{J} \\
\stackrel{\sigma}{=} \\
\stackrel{a}{=}\end{array}$ & \begin{tabular}{l}
0 \\
\multirow{0}{0}{} \\
0 \\
0 \\
0 \\
0 \\
1 \\
1
\end{tabular} & 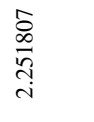 & $\begin{array}{l}0 \\
\infty \\
0 \\
0 \\
0 \\
\infty \\
1 \\
1\end{array}$ & $\begin{array}{l}\infty \\
\infty \\
\tilde{N} \\
\infty \\
\infty\end{array}$ & $\begin{array}{l}\tilde{2} \\
\tilde{n} \\
\stackrel{5}{+} \\
\\
1\end{array}$ & 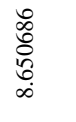 & 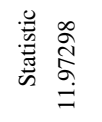 & 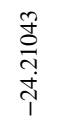 & $\begin{array}{l}\infty \\
\infty \\
\stackrel{\infty}{n} \\
b\end{array}$ \\
\hline & 总高 & 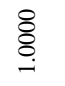 & $\begin{array}{l}8 \\
0 \\
0 \\
0\end{array}$ & $\begin{array}{l}\stackrel{\infty}{\circ} \\
\text { aे }\end{array}$ & 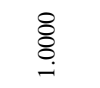 & $\underset{-}{\$}$ & $\begin{array}{l}8 \\
\vdots \\
0\end{array}$ & 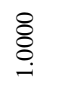 & 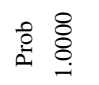 & $\begin{array}{l}8 \\
\vdots \\
0\end{array}$ & $\begin{array}{l}8 \\
8 \\
\wp \\
0\end{array}$ \\
\hline & 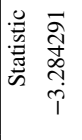 & \begin{tabular}{l}
$\overline{0}$ \\
\multirow{0}{0}{} \\
$\stackrel{0}{\infty}$ \\
\end{tabular} & $\underset{1}{\stackrel{\infty}{+}}$ & 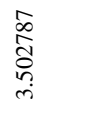 & $\begin{array}{l}n \\
\stackrel{n}{F} \\
\stackrel{m}{i} \\
i\end{array}$ & 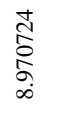 & $\begin{array}{l}\widetilde{O} \\
\stackrel{\circ}{2} \\
\stackrel{1}{1}\end{array}$ & 豙 & 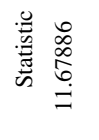 & 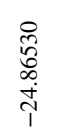 & 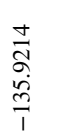 \\
\hline & 을 & $\underset{8}{8}$ & \& & $\underset{-}{8}$ & $\underset{-}{\stackrel{0}{0}}$ & 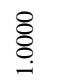 & $\begin{array}{l}8 \\
\vdots \\
0\end{array}$ & $\underset{.}{\circ}$ & 을 & $\begin{array}{l}8 \\
0 \\
0\end{array}$ & $\underset{-}{8}$ \\
\hline \multirow[t]{2}{*}{ 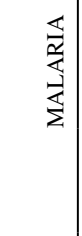 } & 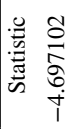 & 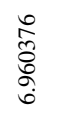 & 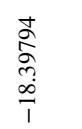 & $\begin{array}{l}a \\
a \\
a \\
a \\
\sigma\end{array}$ & $\begin{array}{l}0 \\
\infty \\
n \\
n \\
a \\
i\end{array}$ & $\begin{array}{l}\infty \\
\infty \\
0 \\
0 \\
i n \\
\infty\end{array}$ & 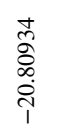 & 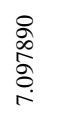 & 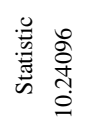 & 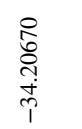 & $\begin{array}{l}\vec{b} \\
\stackrel{0}{0} \\
\stackrel{0}{0}\end{array}$ \\
\hline & 을 & $\underset{8}{8}$ & $\begin{array}{l}8 \\
0 \\
0\end{array}$ & 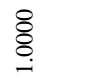 & $\underset{ }{\circ}$ & 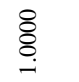 & ¿̊̀ & $\underset{8}{\$}$ & 。̊ & $\begin{array}{l}8 \\
8 \\
0 \\
0\end{array}$ & $\underset{.}{8}$ \\
\hline \multirow{4}{*}{ 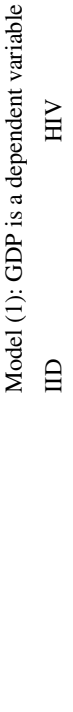 } & 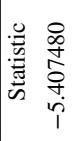 & 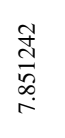 & \begin{tabular}{l}
$\hat{2}$ \\
$\hat{c}$ \\
$\hat{n}$ \\
\multirow{1}{*}{}
\end{tabular} & 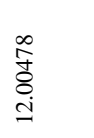 & \begin{tabular}{l}
$\vec{p}$ \\
\multirow{a}{0}{} \\
$o$ \\
$i$ \\
$i$
\end{tabular} & $\underset{\infty}{\stackrel{\infty}{\stackrel{2}{R}}}$ & 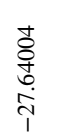 & 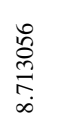 & 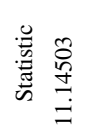 & 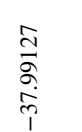 & 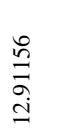 \\
\hline & 웅 & $\underset{8}{8}$ & \&̊. & $\underset{8}{8}$ & $\underset{8}{8}$ & 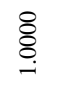 & 灾 & 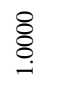 & $\begin{array}{l}0 \\
0 \\
0 \\
0\end{array}$ & \& & @̊ \\
\hline & 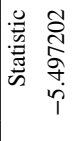 & $\begin{array}{l}\stackrel{a}{\vec{\lambda}} \\
\stackrel{\infty}{0} \\
\infty \\
\infty\end{array}$ & 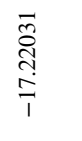 & $\begin{array}{l}\text { 先 } \\
\text { त్ } \\
\text { o. }\end{array}$ & \begin{tabular}{l}
7 \\
\multirow{6}{6}{} \\
-1 \\
0 \\
1
\end{tabular} & $\begin{array}{l}\stackrel{\hat{\infty}}{\infty} \\
\stackrel{\Xi}{=} \\
a\end{array}$ & 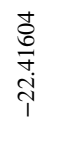 & 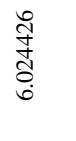 & 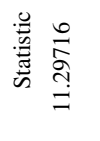 & $\begin{array}{l}\stackrel{2}{2} \\
\stackrel{5}{+} \\
\stackrel{0}{1}\end{array}$ & $\begin{array}{l}\infty \\
\stackrel{0}{0} \\
\substack{0 \\
0}\end{array}$ \\
\hline & 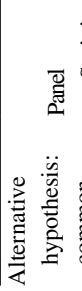 &. & 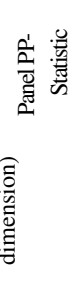 & 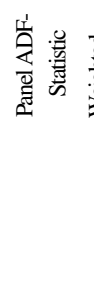 & 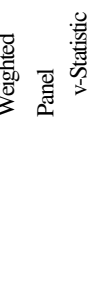 & 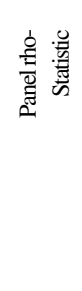 & 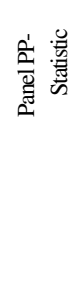 & 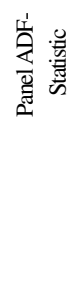 & 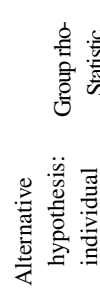 & 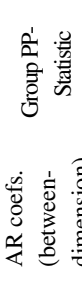 & 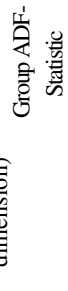 \\
\hline
\end{tabular}




\section{References}

Abdulsalam, S. (2010). Macroeconomic effects of HIV/AIDS prevalence and policy in Nigeria: A simulation analysis. Forum for Health Economics \& Policy, 13(2), 1-24.

AIHW (Australian Institute of Health and Welfare). (2010). Australia's health 2010 Cat no. AUS 122. Canberra: AIHW.

Aksan, A. M., \& Chakraborty, S. (2014). Mortality versus morbidity in the demographic transition. European Economic Review, 70, 470-492.

Alsan, M., Bloom, D. E., \& Canning, D. (2006). The effect of population health on foreign direct investment inflows to low- and middle-income countries. World Development, 34(4), 613-630.

Arceo, E., Hanna, R., \& Oliva P. (2015). Does the effect of pollution on infant mortality differ between developing and developed countries? Evidence from Mexico City. The Economic Journal, 126, pp.257-280.

Baltagi, B. H., Demetriades, P., \& Law, S. H. (2009). Financial development and openness: Evidence from panel data. Journal of Development Economics, 89, 285-296.

Beck, T. (2002). Financial development and international trade: Is there a link? Journal of International Economics, 2, 107-131.

Bleakley, H. (2007). Disease and development: Evidence from hookworm eradication in the American South. The Quarterly Journal of Economics, 122(1), 73-117.

Bleakley, H. (2010). Malaria eradication in the Americas: A retrospective analysis of childhood exposure. American Economic Journal: Applied Economics, 2(2), 1-45.

Bloom, D. E., \& Fink, G. (2014). The economic case for devoting public resources to health. In J. Farrar, N. White, D. Lalloo, P. Hotez, T. Junghanss, \& G. Kang (Eds.), Manson's tropical diseases (23rd ed., pp. 23-30). Elsevier.

Bloom, D. E., Canning, D., \& Sevilla, J. P. (2003). "The demographic dividend. Population Matters", A RAND Program of Policy-Relevant Research Communication, Santa Monica, California.

Bloom, D., Canning, D., \& Fink, G. (2014). Disease and development revisited. The Journal of Political Economy, 122, 1355-1366.

Bloom, D. E., Canning D. (2000). "Health and economic growth: Reconciling the micro and macro evidence", CDDRL Working Paper.

Bloom, D. E., Canning, D., Mansfield, R. K., \& Moore, M. (2007). Demographic change, social security systems, and savings. Journal of Monetary Economics, 54(1), 92-114.

Bloom, D. E., Canning, D., \& Sevilla, J. (2004). The effect of health on economic growth: A production function approach. World Development, 32(1), 1-13.

Bloom, D. E., Kuhn, M., \& Prettner, K. (2017). Africa's prospects for enjoying a demographic dividend. Journal of Demographic Economics, 83(1), 63-76.

Bloom, D. E., Kuhn, M., \& Prettner, K. (2019). Health and economic growth. In: Hamilton, J.H., Dixit, A., Edwards, S., Judd, K. (eds.) Oxford Encyclopedia of Economics and Finance. Oxford, UK: Oxford University Press.

Bloom, D. E., Kuhn, M., \& Prettner, K. (2020). The contribution of female health to economic development. The Economic Journal (forthcoming).

Blouin, C., Chopra, M., \& van der Hoeven, R. (2009). Trade and social determinants of health. Lancet, 373, 502-507.

Bonnel, R. (2000). HIV/AIDS: Does it increase or decrease growth in Africa? World Development, $68(5), 1-25$.

Boucekkine, R., de la Croix, D., \& Licandro, O. (2002a). Vintage human capital, demographic trends, and endogenous growth. Journal of Economic Theory, 104, 340-375.

Boucekkine, R., de la Croix, D., \& Licandro, O. (2002b). Vintage human capital, demographic trends, and endogenous growth. Journal of Economic Theory, 104(2), 340-375.

Bureau for Economic Research. (2006). The macroeconomic impact of HIV/AIDS under alternative intervention scenarios (with specific reference to art) on the South African economy.' Study prepared by the Bureau for Economic Research, University of Stellenbosch, South Africa. (Availableat: https://allafrica. com/download/resource/main/main/idatcs/00010925:073ce79576d8e1bba09905ba47f86dd4.pdf, accessed 13 January 2014.

Cervellati, M., \& Sunde, U. (2005). Human capital formation, life expectancy, and the process of development. American Economic Review, 95(5), 1653-1672. 
Cervellati, M., \& Sunde U. (2011). Life expectancy and economic growth: The role of the demographic transition. Journal of Economic Growth 14(May 2011), 1-35.

Chakraborty, S., Papageorgiou, C., \& Sebastian, F. P. (2010). Diseases, infection dynamics, and development. Journal of Monetary Economics, 57(7), 859-872.

Cole, M. A., \& Neumayer, E. (2006). The impact of poor health on total factor productivity. The Journal of Development Studies, 42(6), 918-938.

Coleman, M., Al-Zahrani, M. H., Coleman, M., Hemingway, J., Omar, A., Stanton, M., Thomsen, E. K., Alsheikh, A. A., Alhakeem, R. F., McCall, P. J., Al Rabeeah, A. A., \& Memish, Z. A. (2013). A country on the verge of malaria elimination-The Kingdom of Saudi Arabia. Lancet, 9, e1059980.

Dauda, R. S., \& Olaniyan, O. (2017). Macroeconomic impact of HIV/AIDS in Nigeria: Error correction modeling (ECM) approach. Advances in Social Sciences Research Journal, 4(4), 31-48.

Derek, Y., Bettcher, D., \& Guindon, G. (2000). Global Trade and Health: Key Linkages and Future Challenges. Bulletin of the World Health Organisation, 78(4), 521-34.

Dhanaraj, S. (2014), "Health shocks and coping strategies: State health insurance scheme of Andhra Pradesh, India”, WIDER Working Paper 2014/003. Helsinki: UNU-WIDER.

Ebenstein, A. (2012). The consequences of industrialization: Evidence from water pollution and digestive cancers in China. Review of Economics and Statistics, 94(1), 186-201.

Ekanayake, E. M., \& Chatrna, D. (2010). The effect of foreign aid on economic growth in developing countries. Journal of International Business and Cultural Studies, 3-11.

Engle, R. F., \& Granger, C. W. (1987). "Co-integration and error correction: representation, estimation, and testing." Econometrica: Journal of the Econometric Society, 251-276.

Fatima, U., Rizvi, S. S. A., Fatima, S., \& Hassan, M. I. (2020). Impact of Hydroxychloroquine/ Chloroquine in COVID-19 Therapy: Two Sides of the Coin. Journal of Interferon \& Cytokine Research, 40(10).

Field, E., Robles, O., \& Torero, M. (2009). Iodine deficiency and schooling attainment in Tanzania. American Economic Journal: Applied Economics, 1, 140-169.

Fortson, J. G. (2011). Mortality risk and human capital investment: The impact of HIV/AIDS in subSaharan Africa. Review of Economics and Statistics, 93, 1-15.

Gallup, J. L., \& Sachs, J. D. (2000). The Economic Burden of Malaria. The American Journal of Tropical Medicine and Hygiene, 64(1-2 Suppl), 85-96.

Garthwaite, C. L. (2012). The economic benefits of pharmaceutical innovations: The case of Cox-2 inhibitors. American Economic Journal: Applied Economics, 4, 116-137.

Genoni, M. (2012). Health shocks and consumption smoothing: Evidence from Indonesia. Economic Development and Economic and Cultural Change, 60, 475-506.

Gries, T., Meierrieks, V., \& Kraft, M. (2009). Linkages Between Financial Deepening, Trade Openness, and Economic Development: Causality Evidence from Sub-Saharan Africa. World Development, 37(12), 1849-1860.

Herzer, D. (2017). The long-run relationship between trade and population health: Evidence from five decades. World Economy, 40, 462-487.

Hyclak, T. J., Skeels, C. L., \& Taylor, L. W. (2016). The cardiovascular revolution and economic performance in the OECD countries. Journal of Macroeconomics, 50, 114-125.

Jack, W., \& Lewis, M. (2009). Health investments and economic growth: Macroeconomic evidence and microeconomic foundations. In M. Spence, \& M. Lewis (Eds.), Health and Growth Chapter 1, Commission on Growth and Development.

Kambou, G., Devarajan, S., \& Over, M. (1993). The economic effects of the AIDS epidemic in SubSaharan Africa: a general equilibrium analysis. Revue d'économie du développement, 1, 37-62.

Kawachi, I., \& Wamala, S. (Eds.). (2006). Globalization and health. Oxford University Press.

Klasing, M. J., \& Milionis, P. (2020). The international epidemiological transition and the education gender gap. Journal of Economic Growth, forthcoming

Lagerlöf, N. P. (2003). From Malthus to modern growth: Can epidemics explain the three regimes? International Economic Review, 44(2), 755-777.

Levin, A., Lin, C. F., \& Chu, C. S. J. (2002). Unit root tests in panel data: Asymptotic and finite-sample properties. Journal of Econometrics, 108, 1-24.

Lindert, P. H. (2004). Growing public: Social spending and economic growth since the eighteenth century (Vol. 1: The story). Cambridge: Cambridge University Press.

Lopez, A. D., Mathers, C. D., Ezzati, M., Jamison, D. T., \& Murray, C. J. L. (Eds.). (2006). Global Burden of Disease and Risk Factors. Oxford University Press. 
Luca, D. L., Iversen, J. H., Lubet, A. S., Mitgang, E., Onarheim, K. H., Prettner, K., \& Bloom, D. E. (2018). Benefits and costs of the women's health targets for the post-2015 development agenda, In Prioritizing development: A cost benefit analysis of the United Nations' Sustainable Development Goals, edited by Bjorn Lomborg, Cambridge University Press, 244-254.

McCarthy, F., Desmold, H. W., \& Yi W. (2000). The Growth Cost of Malaria, NBER Working Paper 7541, February 2000.

McGillivray, M., Feeny, S., Hermes, N., \& Lensink, R. (2006). Controversies over the impact of development aid: it works; it doesn't; it can, but that depends.... Journal of International Development, 18, 1031-1050.

Miljkovic, D., Shaik, S., Miranda, S., Barabanov, N., \& Liogier, A. (2015). Globalisation and obesity. The World Economy, 38(8), 1278-1294.

Ministry of Health, Republic of Angola, Ministry of Health and Social Services, Republic of Namibia. (2010). Trans-Kunene Anti-Malaria Initiative: Implementation Strategy. http://www. rollbackmalaria.org/files/files/countries/TKMIimplementationStrategy-en.pdf

Momota, A., Tabata, K., \& Futagami, K. (2005). Infectious disease and preventive behavior in an overlapping generations model. Journal of Economic Dynamics and Control, 29(10), 1673-1700.

Omri, A, Saida, D., Rault, C., \& Chaibi, A. (2015). Financial development, environmental quality, trade and economic growth: What causes what in MENA countries. Energy Economics, IZA DP No. 8868 .

Over, A. M. (1992). The macroeconomic impact of AIDS in sub-Saharan Africa. Washington, D.C: World Bank.

Owen, A. L., \& Wu, S. (2007). Is trade good for your health? Review International Economics, 15(4), $660-682$.

Paul, G., \& Gruber, J. (2002). Insuring consumption against Illness. The American Economic Review, 92, 51-70.

Pedroni, P. (1999). Critical values for cointegration tests in heterogeneous panels with multiple regressors. Oxford Bulletin of Economics and Statistics, 61, 653-678.

Pedroni, P. (2000). Fully modified OLS for heterogeneous cointegrated panels. Advances in Econometrics, 15, 93-130.

Pedroni, P. (2004). Panel cointegration: Asymptotic and finite sample properties of pooled time series tests with an application to the PPP hypothesis: New results. Econometric Theory, 20(3), 597-627.

Pesaran, H. M., Shin, Y., \& Smith, R. P. (1999). Pooled mean group estimation of dynamic heterogeneous panels. Journal of the American Statistical Association, 94, 621-634.

Pham, N. T. A. (2016). Trade and Economic Development : Evidence from Less Developed Countries. PhD dissertation, University of Adelaide.

Ploetz, R. C., Kema, G. H., \& Jun Ma, L. (2015). Impact of Diseases on Export and Smallholder Production of Banana. The Annual Review of Phytopathology, 53(1), 269-288.

Qureshi, H., \& Mohyuddin, H. (2006). Health status, diseases, and economic development: A crosscountry analysis. The Journal of Developing Areas, 39(2), 121-128.

Rakib, M. (2019). Prevalence of health shocks and the influencing Factors: Evidence from rural Bangladesh. Agriculture, Livestock and Fisheries, 6(3), 363-371.

Schultz, T. P., \& Tansel, A. (1997). Wage and labor supply effects of illness in Côte d'Ivoire and Ghana: instrumental variable estimates for days disabled. Journal of Development Economics, 53, 251-286.

SoIma, K., Pesaran, M. H., \& Shin, Y. (2013). Testing for unit roots in heterogeneous panels. Journal of Econometrics, 115, 53-74.

Stevens, P., Urbach, J., \& Wills, G. (2013). Healthy trade: The relationship between open trade and health. Foreign Trade Review, 48(1), 125-135.

Strauss, J., \& Thomas, D. (2008). Health over the life course. In T.P Schultz, \& J. Strauss (Eds).

Strauss, J., \& Thomas, D. (1998). "Health, nutrition, and economic development." Journal of Economic Literature, 36, 766-817.

Sturrock, H. J., Roberts, K. W., Wegbreit, J., Ohrt, C., \& Gosling, R. D. (2015). Tackling imported malaria: an elimination endgame. The American journal of tropical medicine and hygiene, 93(1), 139-144.

Suhrcke, M., \& Urban, D. (2010). Are cardiovascular diseases bad for economic growth? Health Economics, 19, 1478-1496. 
Sun, A., \& Yao, Y. (2010). Health shocks and school attainments in rural China. Economics of Education Review, 29, 375-382.

Taofik Mohammed, I. (2015). The causal link between trade openness and government size: Evidence from the five largest economies in Africa. International Journal of Business and Economic Sciences Applied Research, 8(1), 121-135.

Trudel-Fitzgerald, C., Millstein, R. A., von Hippel, C., et al. (2019). "Psychological well-being as part of the public health debate?Insight into dimensions, interventions, and policy." BMC Public Health 19, 1712. https://doi.org/10.1186/s12889-019-8029-x

Vo, D. H., \& Vo, A. T. (2017). Currency evaluation using Big Mac index for Thailand: Lessons for Vietnam. Economic Bulletin, 37, 999-1011.

Vo, D. H., Van Huynh, S., Vo, A. T., \& Ha, D.-T. (2019b). The Importance of the financial derivatives markets to economic development in the world's four major economies. Journal of Risk and Financial Management, 12, 35.

Weil, D. N. (2014). Health and economic growth. Chapter 3. In P. Aghion, \& S. N. Durlauf (Eds.), Handbook of Economic Growth. Volume 2. Amsterdam: Elsevier.

WHO. (2013). "What are social determinants of health?", Geneva: WHO. http://www.who.int/social_ determinants/sdh_definition/en/index.html

WHO. (2017). Advancing the right to health: the vital role of law. Library Cataloguing-in-Publication Data, (https://creativecommons.org/licenses/by-nc-sa/3.0/igo).

WHO. (2018). Global Health Expenditure Database. [online] Available at: https://apps.who.int/nha/datab ase/Regional_Averages/Index/en. Accessed 15 Apr 2018.

World Bank. (1993). World Development Report: Investing in Health, (New York: Oxford University Press, 1993).

World Development Indicators (WDI). (2020). World Bank Database. Retrieved from http://data.world bank.org/

World Health Orgnization (WHO). (2020). World Health Orgnization Database. Retrieved from https:// www.who.int/data/gho/publications/world-health-statistics

Woodward, D., Drager, N., Beaglehole, R., \& Lipson, D. (2001). Globalization and health: A framework for analysis and action. Bulletin of the World Health Organization, 79(9), 875-881.

Young, A. (2005). The gift of dying: The tragedy of AIDS and the welfare of future African generations. The Quarterly Journal of Economics, 120(2), 243-266.

Yach, D., \& Bettcher D. (1998). The globalization of public health, II: the convergence of self-interest and altruism. American Journal of Public Health, 88, 738-741.

United Nations. (2019). World economic prospects, New York (2019).

Publisher's Note Springer Nature remains neutral with regard to jurisdictional claims in published maps and institutional affiliations. 